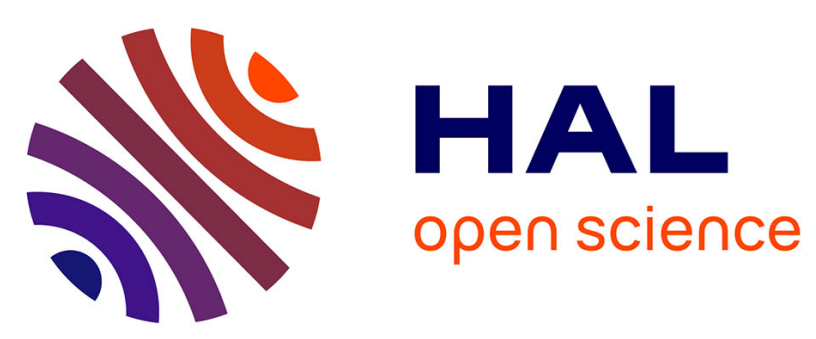

\title{
Diachronous evolution of the alpine continental subduction wedge: evidence from P-T estimates in the Briançonnais Zone houillère (France - Western Alps).
}

Pierre Lanari, Stéphane Guillot, Stéphane Schwartz, Olivier Vidal, Pierre Tricart, Nicolas Riel, Olivier Beyssac

\section{To cite this version:}

Pierre Lanari, Stéphane Guillot, Stéphane Schwartz, Olivier Vidal, Pierre Tricart, et al.. Diachronous evolution of the alpine continental subduction wedge: evidence from P-T estimates in the Briançonnais Zone houillère (France - Western Alps).. Journal of Geodynamics, 2012, 56-57, pp.39-54. 10.1016/j.jog.2011.09.006 . hal-00637845

\section{HAL Id: hal-00637845 \\ https://hal.science/hal-00637845}

Submitted on 3 Nov 2011

HAL is a multi-disciplinary open access archive for the deposit and dissemination of scientific research documents, whether they are published or not. The documents may come from teaching and research institutions in France or abroad, or from public or private research centers.
L'archive ouverte pluridisciplinaire HAL, est destinée au dépôt et à la diffusion de documents scientifiques de niveau recherche, publiés ou non, émanant des établissements d'enseignement et de recherche français ou étrangers, des laboratoires publics ou privés. 


\title{
Diachronous evolution of the alpine continental subduction wedge: evidence from P-T estimates in the Briançonnais Zone houillère (France - Western Alps).
}

\author{
Pierre Lanaria*, Stéphane Guillot ${ }^{\mathrm{a}}$, Stéphane Schwartz ${ }^{\mathrm{a}}$, Olivier Vidal ${ }^{\mathrm{a}}$, Pierre Tricart ${ }^{\mathrm{a}}$. Nicolas \\ Riel $^{\mathrm{a}}$, Olivier Beyssac ${ }^{\mathrm{b}}$, \\ ${ }^{\text {a }}$ ISTerre, Université de Grenoble I, CNRS, 1381 rue de la Piscine. 38041 Grenoble, France. \\ ${ }^{\mathrm{b}}$ IMPMC, Université Pierre et Marie Curie, CNRS, 4, place Jussieu, 75005 Paris, France. \\ * corresponding author: Pierre Lanari \\ e-mail adress: pierre.lanari@ujf-grenoble.fr, fax number: +33476514058.
}

\begin{abstract}
The study of continental subduction processes requires detailed Pressure Temperature (P-T) paths to understand the kinematic of burial and exhumation of continental units. In the French Western Alps, the Briançonnais zone is a remnant of the continental subduction wedge. P-T conditions have been estimated in its most internal parts, but there is a lack of data in the western part, known as the "Zone houillère". This Briançonnais Zone houillère is classically divided into two sub-units: the upper and lower Houiller units. This study focuses on both of these in the Clarée valley, north of Briançon. In this low-grade metamorphic terrain, estimation of P-T history is complicated because there are few adapted methods and these rocks have a poor metamorphic mineralogical content, including detrital metamorphic minerals inherited from their hercynian history. Therefore, to acquire accurate P-T estimates a multi-method approach is required, involving qualitative and quantitative Raman study of Carbonaceous Material (RSCM), chemical analysis from quantified X-ray maps and thermodynamic modelling of chlorites and K-white micas. Such multi-approach P-T estimates on a sandstone sample allow distinguishing hercynian peak metamorphic conditions of $371 \pm 26^{\circ} \mathrm{C}$ and $3.5 \pm 1.4 \mathrm{kbar}$ and alpine peak metamorphic conditions of 275 $\pm 23^{\circ} \mathrm{C}$ and $5.9 \pm 1.7 \mathrm{kbar}$. These results are consistent with our RSCM and $\mathrm{T}_{\max }$ estimates. Raman study conducted on organic-rich schist samples shows an eastward increase of the alpine $\mathrm{T}_{\max }$ in the upper Houiller unit, from 280 to $300^{\circ} \mathrm{C}$ across the Briançonnais Zone houillère. In contrast, carbonaceous material included in detrital grains of muscovite in the sandstone exhibits higher temperatures. This hercynian $\mathrm{T}_{\max }$ is estimated using thermodynamic modelling at $376 \pm 50^{\circ} \mathrm{C}$. According to these results and previous work in more internal parts of the Briançonnais zone, a geodynamic reconstruction is proposed, which is characterized by a diachronous evolution of the Briançonnais zone involved in alpine continental subduction at different times. The geothermal gradient in the Briançonnais zone changes from $8^{\circ} \mathrm{C} / \mathrm{km}$ during early continental subduction, to $40^{\circ} \mathrm{C} / \mathrm{km}$ during the collisional event at about $35-30 \mathrm{Ma}$. The intermediate gradient of $15^{\circ} \mathrm{C} / \mathrm{km}$ estimated in the Briançonnais Zone houillère suggests that this unit was buried later, than the more internal Briançonnais units, after $40 \mathrm{Ma}$.
\end{abstract}

Keywords: Continental subduction; P-T path; low-grade metamorphism; geodynamic; Western Alps. 


\section{1) Introduction:}

Since the discovery of UHP mineral parageneses in continental rocks in the Alps and in Norway (Chopin, 1984; Smith, 1984), the concept of continental subduction has been thoroughly investigated worldwide (e.g. Guillot et al., 2009 for a review). One of the main open questions concerns the size of exhumed continental units during their syn-collisional evolution. Young et al. (2007) recently proposed that only large-scale units (hundreds of $\mathrm{km}^{2}$ ) can be exhumed. In the French Western Alps, the Briançonnais zone is a remnant of the continental subduction wedge. This domain outcrops in a $1200 \mathrm{~km}^{2}$ area, sandwiched between the oceanic subduction paleo-wedge (Piedmont internal zone) and the collision paleo-wedge (external zone). This configuration makes it a strategic area for understanding the thermal evolutions and therefore the continental subduction processes. Several studies have been conducted over the last ten years, which were aimed at constraining the evolution of Pressure-Temperature (P-T) conditions of the internal parts of the wedge such as the Vanoise and Ambin massifs of the Brianconnais Zone, during the Alpine orogeny (Ganne, 2003; Ganne et al. 2003, 2005, 2007; Gerber, 2008; Strzerzynski et al., this issue). In contrast, the metamorphic evolution of the external part of the Briançonnais Zone, known as the "Zone houillère", remains largely unconstrained (Gabalda et al., 2009). P-T conditions recorded by the Briançonnais Zone houillère during alpine continental collision are not well established. This low-metamorphic-grade terrain consists of a stack of Carboniferous and Permian metasediments and volcanics. Metasediments are composed of organic-rich schist and sandstone levels with a poor and monotonous mineralogy (mostly phyllosilicates), which have hampered P-T estimates using classical thermobarometric approaches.

The first metamorphic conditions derived in the Briançonnais Zone houllière were empirical estimates from index mineral occurrences (see the lawsonite example in Saliot, 1978; Frey et al., 1999; Goffé et al., 2004, Bousquet et al., 2008). More recently, Ceriani et al. (2003) estimated both temperature and pressure in the Saint-Martin de Belleville area using the $\mathrm{K}$-white mica b-cell method, combined with illite crystallinity and fission-track analysis. They proposed a temperature of $280-300^{\circ} \mathrm{C}$ at a pressure of $3.5 \mathrm{kbar}$. Further south in the Arc valley (Fig. 1), Gabalda et al. (2009) conducted a detailed study of thermal metamorphism using RSCM thermometry (Raman Study of Carbonaceous Material). This method (see \$4.1) provides the maximal temperature $\left(\mathrm{T}_{\max }\right)$ reached by a sample during metamorphism. The study of Gabalda et al. (2009) exhibited an eastward increasing $\mathrm{T}_{\max }$ trend from $346 \pm 50^{\circ} \mathrm{C}$ to $389 \pm 50^{\circ} \mathrm{C}$. The authors suggested these $\mathrm{T}_{\max }$ are most likely Alpine in age, based on the presence of lawsonite in the median and eastern part of the Briançonnais Zone houillère (Goffé et al., 2004; Frey et al., 1999). However, the occurrence of lawsonite at such temperatures would imply a pressure higher than 8-10 kbar (Spear, 1993), which is not compatible with the estimation of Ceriani et al. (2003). Furthermore, Zircon Fission Track (ZFT) analysis in the western part of the Arc valley, and further north (same location as that studied by Ceriani et al. (2003)), provided ages between $70 \mathrm{Ma}$ and $90 \mathrm{Ma}$ (Fügenschuh \& Schmid, 2003; Ceriani et al., 2003). These ages, which are intermediates between Hercynian and Alpine ages, indicate incomplete Tertiary annealing, as there is no evidence of a cretaceous metamorphic event in the Briançonnais Zone houillère. The upper thermal limit of the zircon partial-annealing zone thus provides an estimate about the maximum temperature reached during the alpine event. Depending of the zircon type (amount of $\alpha$-damage), the upper limit of the zircon partial-annealing temperature varies from $240^{\circ} \mathrm{C}$ (Brandon et al., 1998; Bernet, 2009) to $300^{\circ} \mathrm{C}$ (Tagami et al., 1998). The temperatures obtained by Gabalda et al. (2009) in the western part of their transect in the Briançonnais Zone houillère are higher 
than the experimentally determined zircon annealing temperatures. They are most likely overestimated by about $50^{\circ} \mathrm{C}$. This review of metamorphic data in the Briançonnais Zone houillère reveals a great paucity of $\mathrm{P}-\mathrm{T}$ data, and an apparent incompatibility between the different available estimates. All metamorphic domains along a transect from the Pelvoux external crystalline massif to the Dora Maira internal crystalline massif are well documented (Agard et al., 2001, 2002; Ganne, 2003; Ganne et al., 2003, 2005, 2007; Schwartz et al., 2007; Gerber, 2008; Gabalda et al., 2009; Strzerzynski et al., this issue; Simon-Labric et al., 2009) except for the Briançonnais Zone houillère. Therefore we focus our investigation on the Briançonnais Zone houillère in the Clarée valley to the south of the area studied by Gabalda et al. (2009).

P-T estimates in low-grade metamorphic terrains are difficult; we propose a multiapproach metamorphic study here, which consists of a combination of chemical mapping, thermodynamic modelling and RSCM thermometry. Chemical mapping allows the identification of pre-alpine, inherited detrital minerals and new metamorphic minerals growing during the alpine orogeny. It requires measurement of quantified maps of composition using the method proposed by De Andrade et al. (2006). The P-T conditions of metamorphism were estimated from the composition of chlorites and K-white micas in equilibrium (Vidal \& Parra, 2000; Vidal et al., 2005; 2006; Dubacq et al., 2010). In the present study, the combination of chemical mapping and multi-equilibrium calculations allows construction of a well-resolved P-T path. Unfortunately, the application of such approaches is complex and time-consuming. For this reason, only a single sample has been studied. The results are compared with RSCM thermometry conducted in the Clarée Valley on a large set of samples to estimate the $T_{\max }$ of metamorphic events (Beyssac et al., 2002).

The aim of this study is (1) to propose a multi-method approach to estimate P-T conditions in low-grade metamorphic terrains with detrital mineral fractions, (2) to establish a structural cross-section across the Briançonnais Zone houillère between the Pelvoux external crystalline massif and the internal Briançonnais zone (AA' in Fig. 1) and (3) to compare structure, microstructures and P-T estimates at the local and regional scales in order to discuss the burial and exhumation dynamics of the Briançonnais zone.

\section{2) Geological setting:}

\section{1) Regional geology:}

In the core of the Western alpine arc, the internal metamorphic zones consist of a stack of oceanic and continental-margin derived nappes (e.g. Graciansky et al., 2010 with references therein). This nappe stack results from Mezozoic - Cenozoic convergence between the european and adrian (african) continental plates, accomodated by subduction and collision processes (see Schmid and Kissling, 2000 for a review). Oceanic units (Piedmont Schistes lustrés nappes and associated ophiolites) are derived from the ligurian segment of the Mesozoic Tethyan ocean. Their complex structure results from severe syn-collisional refolding of the subduction wedge (Tricart \& Schwartz, 2006, Lardeaux et al., 2006) and presents a eastward increasing in metamorphic gradient temperature (Rolland et al., 2000; Schwartz, 2000; Agard et al., 2001; Gabalda et al., 2009; Schwartz et al., 2009). The oceanderived zone is currently sandwiched between austroalpine (african) and european nappe stacks. Within the latter, the Briançonnais zone is classically divided into two sub-zones (Barféty et al. 2006a) separated by the Internal Houiller Front (IHF in Fig. 1). To the West, the external Briançonnais zone presents relatively comprehensive Mesozoic sedimentary 
series with a Carboniferous substratum: the Briançonnais Zone houillère. This unit exhibits low-grade alpine metamorphism (Saliot, 1978; Caby, 1996; Le Fur, 1998; Frey et al. 1999; Goffé et al. 2004). To the east, the internal Briançonnais zone presents a thinner Mesozoic sedimentary cover on top of a basement consisting of pre-Carboniferous metamorphic terrains (like the Ambin massif in Fig. 1).

The Briançonnais Zone houillère is classically divided into the upper and the lower Houiller units (Fig. 1), both constituted by polygenetic conglomerates, sandstones, organicrich schists and anthracite levels intruded by volcanic sills and dykes (Mercier \& Beaudoin, 1987; Barféty et al., 2006b). The Drayère shear zone separates the upper and lower Houiller units. Along this fault, stretching lineations and shear bands indicate a ductile extensional regime (Caby, 1996). Fabre (1982) also noted that the Drayères shear zone is probably superimposed on an inherited Palaeozoic fault. The Drayère shear zone was defined in the Clarée valley (eastern bank of the Clarée river, Fig. 2) and the continuity further north remains poorly defined. The northern part of the contact between upper and lower Houiller units (dashed line in Fig. 1) appears as a stratigraphic contact (Bertrand, 2009 personal communication). The disappearance of the lower Houiller unit further north is associated with a southern axial plunge of folds in both Houiller units (Fabre et al., 1982; Caby, 1996), which corresponds to gradually deeper crustal levels exposed northward (Ceriani, 2001).

\section{2) Structural evolution of the Briançonnais Zone houillère:}

For a long time the Briançonnais Zone houillère has been described as a fan structure (Kilian, 1903; Fabre, 1982; Detraz, 1984; Caby, 1996; Ceriani, 2001). In effect, the external Houiller front exhibits a top-to-the-west thrusting direction, and the internal Houiller front a top-to-the-east thrusting (i.e. backthrusting) direction (Figs. 1 and 3). This simple fan shape accounts for some of the main structural features such as $\mathrm{km}$-size recumbent folds facing toward the west in the western part and towards the east in the eastern part. Just to the south, in the Briançonnais sedimentary cover nappes, Tricart (1984) demonstrated that after initial nappe stacking associated with a first foliation development, two main shortening events occurred: (1) west-directed folding and thrusting linked to activity of the Briançonnais frontal thrust and (2) east-verging folding and top-to-the-east thrusting, associated with "backtrusting" of the Briançonnais zone onto the Piedmont Schistes lustrés complex. These Oligocene post-nappe shortening phases were followed by ductile then brittle extension from the Neogene onwards (Tricart \& Schwartz, 2006).

The most recent model by Bertrand et al. (1996) proposed an alternative scenario comprising three compressional stages, followed by a late extensional one (Table 1) based on observations in the lower Houiller unit further north. The D1 deformation event is characterized by an intense and penetrative S1 schistosity (Ceriani, 2001), oriented subparallel to S0 in strongly deformed layers. Several authors have interpreted this event resulting from the initial piling up of different thrust sheets (Tricart, 1980; 1984; Fabre et al., 1982; Detraz, 1984; Aillières et al., 1995; Bertrand et al., 1996; Gabalda et al., 2009). The kinematic interpretation of D1 event is not easy, because there is no associated stretching lineation, while evidences of duplication (Fabre et al., 1982) or F1 isoclinal folds are extremely scarce (Bertrand et al., 1996; Ceriani, 2001). The D2 event develops large-scale F2 recumbent folds associated with the $\mathrm{S} 2$ regional schistosity. In the middle to eastern part of the Briançonnais Zone houillère, S2 consistently dips to the West. The D3 event is strongly localized and F3 folds correspond to multi-scale low amplitude bending of S2 foliation. 
These F3 folds are associated with a sub-horizontal S3 schistosity (Aillères et al., 1995; Bertrand et al., 1996; Caby, 1996). Bertrand et al. (1996) suggest that this D3 event, which shows a top-to-the west vergence, is responsible for the fan geometry of the Briançonnais Zone houillère. In effect, the apparent eastward facing of the F2 folds may be due to the bending of D2 structures around large-scale F3 folds. This polyphased story showing a topto-the west vergence, has already been described by Fabre et al. (1982), but without detailed interpretation.

\section{3) Studied area - The Clarée valley:}

The studied area is located in the Clarée valley (Fig. 2), $20 \mathrm{~km} \mathrm{NNW}$ of the town of Briançon. There, excellent outcropping conditions offer the opportunity to study both the upper and lower houiller units. The area west of the Drayère shear zone exhibits lower houiller unit with fragments of its related Mesozoic cover involved in the Queyrellin and the "Aiguillette du Lauzet" synclinal folds (Fig. 3). The axial surfaces of these km-size folds display a fan shape, which is in part linked to proximity of the external houiller front. Only one penetrative schistosity S1, with a steep dip to the east, is visible in less competent layers. In contrast, in the upper houiller unit east of the Drayère shear zone, intense ductile deformation is displayed by $\mathrm{m}$ to $\mathrm{km}$-size recumbent folds, associated with top-to-the east shearing. The first schistosity S1 is penetrative and turns within the F2 folds, which present an axial plane S2 schistosity dipping to the west (Fig. 3). In this area, the S1 schistosity is sub-parallel to S0.

In the Clarée valley, the Briançonnais Zone houillère commonly presents only two deformation phases (Table 1). The first phase, D1, is linked to the westward propagation of thrusting activity associated with the Drayère shear zone (noted 1 in Fig. 3). Along this shear zone, higher grade metamorphic rocks overthrust lesser grade metamorphic rocks, implying that D1 event corresponds to the exhumation of Briançonnais Zone houillère units. The second phase, D2, is related to the "backthrusting" phase, with top-to-the-east shearing. This event involved folding of the Drayère shear zone as illustrated in Fig. 3. In the Rochille sector (Permian series in the NW corner of Fig. 2) a third deformation phase, D3, with top-tothe west horizontal shearing has been identified by Fabre et al. (1982). The sequence of events presented here does not differ significantly from those proposed previously.

\section{3) Sampling:}

The Briançonnais Zone houillère in the Clarée Valley exhibits essentially two useful types of lithologies: organic-rich schists and sandstones. The latter are rich in detrital minerals. For this study, eight samples were collected (Fig. 2 and table 2). Seven samples are organic-rich schists and are characterized by a high content of carbonaceous materials (CM) and various amounts of phyllosilicates, small grain of quartz and feldspars. The carbonaceous material consists of microcrystal agglomerates (framboids) underlining the schistosity, with sizes between $8,000 \mu \mathrm{m}^{2}$ and $40,000 \mu \mathrm{m}^{2}$. A few detrital minerals $(<1 \%)$ are found as flakeshaped muscovites with width less than $5 \mu \mathrm{m}$. Organic-rich schist samples are spread over the area with two samples in the "Le Chardonnet" sector in the lower houiller unit and eight samples in the upper houiller unit (Fig. 2). For this study, this upper houiller unit is divided into two sectors, the "Laval" sector and "Cula" sector further west (Fig. 2).

The last sample (PL08-74, star in Fig. 2) is a sandstone from the "Laval" sector. It has a high content of detrital minerals such as chlorite and micas. Some flakes of detrital muscovite and chlorite are visible in thin section (Fig. 4b) and identified as $\mathrm{H}$ minerals in Fig. 
6 and Fig. 7 (H1 and H2). This sample exhibits two schistosities (S1 and S2 in Fig. 6 and Fig. 7) and comes from the hinge zone of an east-verging F2 fold in the upper houiller unit, close to the Drayère shear zone. The CM content is lower than that of the organic-rich schists. Carbonaceous material appears in microcrystals agglomerates (Fig. 4a) and is included within detrital minerals like muscovites (Fig. 4b). Inclusions of CM have flake shapes of $500 \mu \mathrm{m}^{2}$ to $1000 \mu \mathrm{m}^{2}$, and lie in muscovite cleavage planes.

Different methods have been used to analyse these samples. RSCM thermometry has been performed on organic-rich samples in order to estimate the maximal temperature $\left(\mathrm{T}_{\max }\right)$. RSCM thermometry allows reconstructing the thermal structure of an orogen during their metamorphic thermal peak (Beyssac et al., 2002; 2007; Negro et al., 2006; Gabalda et al., 2009; Lahfid et al., 2010). Our data provide the first results from the upper houiller unit. Unfortunately RSCM thermometry provides only the Tmax and advanced investigations are required to estimate both $\mathrm{P}$ and $\mathrm{T}$ and to build consistent $\mathrm{P}-\mathrm{T}$ paths. Thermodynamic computations were realized on the sandstone sample with a high detrital mineral content to construct P-T paths. The combination of both methods provides an excellent framework to study low-grade metamorphic areas.

\section{4) Analytical and thermobarometric methods:}

\section{1) Raman spectrometry of carbonaceous material:}

Organic matter present in rocks is gradually transformed into $\mathrm{CM}$ during regional metamorphic processes. This progressive graphitization process can be used for the estimation of peak temperature $\left(\mathrm{T}_{\max }\right)$ reached by the studied sample (Beyssac et al., 2002, 2003a). The degree of graphitization is controlled by temperature during regional metamorphism (Beyssac et al., 2002, 2003b). Moreover, graphitization is an irreversible process, so that retrograde metamorphic reactions do not affect the temperature estimates. This thermometer is based on the quantification of the degree of ordering of CM using the R2 area ratio between the graphite $\mathrm{G}$ band and the $\mathrm{D} 1$ and $\mathrm{D} 2$ defect bands $(\mathrm{R} 2=\mathrm{D} 1 /$ [G+D1+D2])) extracted from the Raman spectra (Beyssac et al., 2002). Beyssac et al. (2002) showed that the $\mathrm{R} 2$ ratio is linearly correlated with the $\mathrm{T}$ max of the metamorphic cycle $\left(\mathrm{T}_{\max }\right.$ $\left.\left({ }^{\circ} \mathrm{C}\right)=-445 . \mathrm{R} 2+641\right)$. This correlation may be used as a thermometer with an intrinsic error calibration of $50^{\circ} \mathrm{C}$ due to the petrological data used for calibration, but lower relative accuracy of about $15^{\circ} \mathrm{C}$ (Beyssac et al., 2004).

For Tmax below $330^{\circ} \mathrm{C}$, the Raman spectra of $\mathrm{CM}$ are different with two additionnal bands (D3 and D4), which require a different fitting procedure (Lahfid et al., 2010). Lahfid et al. (2010) performed a systematic study of the evolution of the Raman spectrum of CM in low-grade metamorphic rocks in the Glarus Alps (Switzerland). They showed that the Raman spectrum of $\mathrm{CM}$ exhibits a significant evolution in the relative contributions of the different bands with increasing $\mathrm{T}$ in the range $200-350^{\circ} \mathrm{C}$. A new ratio Ral (RA1 $=[\mathrm{D} 1+\mathrm{D} 4] /$ $[\mathrm{D} 1+\mathrm{D} 2+\mathrm{D} 3+\mathrm{D} 4+\mathrm{G}])$ quantifying the degree of ordering of $\mathrm{CM}$ is linearly correlated with increasing $\mathrm{T}\left(\mathrm{T}_{\max }\left({ }^{\circ} \mathrm{C}\right)=(\mathrm{Ra} 1-0.3758) / 0.0008\right)$ in the case of the Glarus Alps. Using this correlation, which is not a universal calibration (see discussion in Lahfid et al., 2010) may provide first-order insights in the thermal evolution of rocks in the Zone houillère, which are characterized by a similar protolith and geological setting.

All Raman spectra have been measured following the procedure of Beyssac et al. (2002, 2003a, 2007). Polished thin sections were used and analyses were performed through a transparent adjacent mineral. The most common mineral used is quartz, because it does not 
have Raman bands in the studied range. Raman spectra were obtained using a Renishaw InVIA Reflex microspectrometer (IMPC, Université Pierre et Marie Curie, Paris) with a 514$\mathrm{nm}$ argon laser. The laser power at the surface was set around $1 \mathrm{~mW}$. This laser was focused on the sample using a DMLM Leica microscope with a $\times 100$ objective (numerical aperture $=$ 0.85). The signal was filtered by edge filters and finally dispersed using a 1800 lines $/ \mathrm{mm}$ grating to be analysed by a Peltier cooled RENCAM CCD detector. The Raman spectrometer was calibrated with a silicon standard. For each sample, 10 to 20 spectra (noted $n$ in table 2) were recorded with $2 \times 60$ s acquisition times. The fitting procedure (Beyssac et al., 2002, 2007, Lahfid et al., 2010) was performed using the software PeakFit v4.

\section{2) EPMA point analyses and X-ray map of composition}

Electron probe microanalyser (EPMA) point analyses were made with common calibration at conditions of $15 \mathrm{Kev}$ and 10nA. In order to study the relationship between phyllosilicate composition and rock structure, quantitative maps of composition were also acquired and standardized according to the procedure of De Andrade et al. (2006). The mapping conditions were $15 \mathrm{Kev}$ and $100 \mathrm{nA}$, with a counting time of $300 \mathrm{~ms}$ per grid point. These conditions enable to measure a map of $450 \times 450$ pixels $(>2,000,000$ analyses $)$ with a total measurement time of around $33 \mathrm{~h}$. For each mineral, a series of pixels was measured in point mode, and results were used as internal standards to transform the map of photon intensity into maps of elements concentration. EPMA analyses of the PL08-74 sandstone sample were performed at Université Pierre et Marie Curie (CAM Paris), using a CAMECA SX 100 instrument. Standards used were diopside ( $\mathrm{Si}, \mathrm{Mg}, \mathrm{Ca})$, orthose (Al, K), $\mathrm{MnTiO}_{3}$ $(\mathrm{Mn}, \mathrm{Ti})$, garnet $(\mathrm{Fe})$ and albite $(\mathrm{Na})$. The beam size diameter was routinely set at $2 \mu \mathrm{m}$. The raw composition maps were transformed into quantitative maps using high quality point analyses of all phases present in the mapped area (see De Andrade et al., 2006). This was achieved using our Matlab-GUI software (XMapTools 1.04, http://www.xmaptools.com) that can be used to treat the raw analyses and display the results as binary or ternary plots. This software was also used to calculate the crystallization temperatures of chlorite (one estimated temperature per chlorite pixel) and pressures from of phengite (see below).

\section{3) Chlorite-Quartz-Water thermometer}

With increasing grade of metamorphism, chlorite shows increasing $\mathrm{Al}^{\mathrm{IV}}$ (Cathelineau \& Nieva, 1985; Cathelineau, 1988; Hillier \& Velde, 1991; Zang \& Fyfe, 1995) and decreasing vacancy contents (Cathelineau \& Nieva, 1985; Vidal et al., 2001). The observed evolution of composition with temperature can be modelled with the following equilibria (Vidal et al., 2005, 2006):

$5 \mathrm{Mg}$-Amesite +4 Daphnite $\leftrightarrow 4$ Clinochlore +5 Fe-Amesite

2 Clinochlore +3 Sudoite $\leftrightarrow 4 \mathrm{Mg}$-Amesite +7 Quartz $+4 \mathrm{H}_{2} \mathrm{O}$

16 Daphnite +15 Sudoite $\leftrightarrow 6$ Clinochlore $+20 \mathrm{FeAmesite}+35$ Quartz $+20 \mathrm{H}_{2} \mathrm{O}$

4 Daphnite +6 Sudoite $\leftrightarrow 3 \mathrm{Mg}$-Amesite $+5 \mathrm{Fe}$-Amesite +14 Quartz $+8 \mathrm{H}_{2} \mathrm{O}$

where clinochlore (Clin), Mg-amesite (Am), Fe-amesite (Fe-Am), daphnite (Daph), and sudoite (Sud) are end-members of chlorite coexisting with quartz and water. The temperature locations of the equilibria (1) to (4) depend on the activity of the Clin, Daph, Sud and amesite end-members as well as the activity of water. At fixed water activity and pressure, an increase in sudoite component (increase in vacancies) and Clin + Daph components (increase in $\mathrm{Si}$ ) 
leads to a shift in the equilibria at lower temperatures, consistent with numerous empirical thermometers based on the amount of $\mathrm{Al}^{\mathrm{IV}}$ in chlorite (e.g. Cathelineau \& Nieva, 1985; Cathelineau, 1988; Hillier \& Velde, 1991; Inoue et al., 2009). Vidal et al. (2005; 2006) suggested that a simultaneous estimation of $\mathrm{Fe}^{3+}$ in chlorite and equilibrium temperature for the Chl-Qtz- $\mathrm{H}_{2} \mathrm{O}$ assemblage can be performed using criterion based on the convergence of equilibria (1) to (4) at a given pressure, which is achieved for a minimal $\mathrm{XFe}^{3+}=\left(\mathrm{Fe}^{3+} / \mathrm{Fetot}\right)$ of chlorite. For a given chlorite composition (and thus end-member activities), $\mathrm{XFe}^{3+}$ is increased until convergence of (1) to (4) is obtained at given pressure. This method has been validated qualitatively by comparing estimated values of $\mathrm{XFe}^{3+}$ with XANES measurements (Vidal et al., 2006; Munoz et al., 2006).

Temperature and $\mathrm{XFe}^{3+}$ were estimated at a fixed pressure of $4 \mathrm{kbar}$ and a water activity equal to 1 . Convergence was considered to be achieved when the temperature difference between all equilibria (1) to (4) was less than $30^{\circ} \mathrm{C}$. This value was adopted in order to take into account the cumulative uncertainties stemming from errors in the thermodynamic data of the chlorite end-members, solid solution properties and the analytical uncertainties.

\section{4) Phengite-Quartz-Water thermometry:}

Following the earlier work of Velde (1965), Massone \& Schreyer (1987) proposed a relationship between pressure and $\mathrm{Si}$ content per formula unit (pfu) of phengites for the system $\mathrm{K}_{2} \mathrm{O}-\mathrm{MgO}-\mathrm{Al}_{2} \mathrm{O}_{3}-\mathrm{SiO}_{2}-\mathrm{H}_{2} \mathrm{O}$ (KMASH) for $\mathrm{K}$-white-mica coexisting with $\mathrm{K}$-feldspar, quartz and phlogopite. These studies indicated that at fixed bulk-rock composition, the extent of the Tschermak substitution and therefore the Si content of phengite increases with pressure. At low temperature, the Si content of dioctahedral mica is also controlled by the pyrophyllitic substitution, which is responsible for an increase of $\mathrm{Si}$ and a decrease of interlayer content (IC, excluding interlayer water) with decreasing T (Bishop \& Bird, 1987; Cathelineau, 1988; Agard et al., 2000; Parra et al., 2002a, 2002b; Battaglia, 2004). The vacant sites of LT and LP illites are partially hydrated (Loucks, 1991; Drits \& McCarty, 2007, Vidal \& Dubacq, 2009; Dubacq et al., 2010; Vidal et al., 2010). Dubacq et al. (2010) proposed a formalism that involves dehydrated micas and hydrated pyrophyllite-like thermodynamic end-members to model these compositional variations as a function of $\mathrm{T}$ and $\mathrm{P}$. The equilibrium conditions of quartz + water $+\mathrm{K}$-mica is represented by a divariant P-T line along which the interlayer water content varies. The P-T location of this line can be calculated from equilibrium conditions of the following equilibria:

3 Celadonite +2 Pyrophyllite $\leftrightarrow 2$ Muscovite + Biotite +11 Quartz $+2 \mathrm{H}_{2} \mathrm{O}$

3 Celadonite +2 Pyrophyllite. $1 \mathrm{H}_{2} \mathrm{O} \leftrightarrow 2$ Muscovite + Biotite +11 Quartz $+3 \mathrm{H}_{2} \mathrm{O}$

Pyrophyllite. $1 \mathrm{H} 2 \mathrm{O} \leftrightarrow$ Pyrophyllite $+\mathrm{H}_{2} \mathrm{O}$

where celadonite, pyrophyllite, pyrophyllite. $1 \mathrm{H} 2 \mathrm{O}$, muscovite and biotite are solid solution components of the mica phase. Dubacq et al. (2010) showed that the mica-quartz-water equilibrium could be used as a barometer at given temperature conditions (e.g. from chloritequartz-water thermometry, see above).

\section{5) Thermobarometric Results:}

5.1) $T_{\max }$ estimates: 
Two types of spectra were obtained from CM measured through different transparent minerals (Fig. 4). The first type, measured through quartz, presents features characteristic of $\mathrm{T}_{\max }<330^{\circ} \mathrm{C}$ (Lahfid et al., 2010): the D band exhibits a shoulder close to $1200 \mathrm{~cm}^{-1}$ and the region between the $\mathrm{D}$ and $\mathrm{G}$ bands exhibits high intensity, indicating the presence of a welldeveloped D3 band. An average $\mathrm{T}_{\max }=283^{\circ} \mathrm{C}\left(1 \sigma=4^{\circ} \mathrm{C}\right)$ was obtained from these spectra when applying the calibration proposed by Lahfid et al. (2010) using the ratio Ra1 (PL08-74 in Table 2). The second type of spectra measured through detrital muscovite and chlorite (Fig. 4b) have different shapes and exhibit a shoulder on the $G$ band, the D2 band defined by Beyssac et al. (2002). A temperature of $390^{\circ} \mathrm{C}$ was calculated from three spectra (Fig. 4b) measured in detrital muscovite with $1 \sigma=4^{\circ} \mathrm{C}$. The large difference between the temperatures obtained by RSCM using CM included in quartz or in phyllosilicate will be discussed later.

In organic-rich schist samples, spectra are characteristic of low-temperature conditions and the thermometer of Lahfid et al. (2010) provides values of $\mathrm{T}_{\max }<310^{\circ} \mathrm{C}$. Results are summarized in Table 2 and projected in a cross section of the Briançonnais Zone houillère (Fig. 5). From west to east, the estimated $\mathrm{T}_{\max }$ were around $296^{\circ} \mathrm{C}, 283^{\circ} \mathrm{C}$ and $306^{\circ} \mathrm{C}$ for the "Chardonnet", "Laval" and "Cula" areas, respectively. These results show that $\mathrm{T}_{\max }$ are roughly constant in the Briançonnais Zone houillère with variations $<30^{\circ} \mathrm{C}$.

\section{2) Chemical variations and geothermometry: K-White-Micas:}

Detrital Hercynian grains are commonly observed in low-grade metasediments. In our case, large flakes of detrital micas (noted $\mathrm{H}$ in fig. 6) are preferentially re-oriented in the S1 plane and sometimes kinked by S2. However, microstructural criteria are not sufficient to distinguish hercynian and alpine micas. In contrast, several generations of K-white-mica can be clearly distinguished from their contrasted compositions. The most important compositional variations of mica derived from the X-ray map involve the $\mathrm{Na}$ and Si contents (Figs. 6 and 8). Compositional maps highlight the coexistence of Si-poor and Na-rich mica grains (H1 and $\mathrm{H} 2$ in Fig. 6) with Si-rich and Na-poor mica grains (A1g1 and A1g2 in Fig. 6). Detrital mica $(\mathrm{H})$ were divided into two groups according to their Na-content: H1 micas have Na-content ranging from 0.15 to $0.2 \mathrm{pfu}$ and $\mathrm{H} 2$ from 0.07 to $0.13 \mathrm{pfu}$. The most Si-rich micas (A), show Na-content lower than 0.07 pfu. They were also split into two groups: A1g1 for Si-contents between 3.45 and $3.32 \mathrm{pfu}$ and A1g2 for Si-contents between 3.32 and 3.15 pfu (Fig. 8b).

The Phengite-Quartz-Water method of Dubacq et al. (2010) was applied to each pixel of mica groups (H1, H2, A1g1 and A1g2) selected on the X-Ray map. For each pixel of mica, a P-T line was calculated; the results are plotted in Fig. 10a. $\mathrm{H} 1$ and $\mathrm{H} 2$ groups show temperatures at $330^{\circ} \mathrm{C}$ and $375^{\circ} \mathrm{C}(\mathrm{P}=4 \mathrm{kbar})$, respectively. In contrast, A1 mica shows temperatures lower than $300^{\circ} \mathrm{C}$ at the same pressure. Detrital $\mathrm{H}$ micas have a low Si-content and are identified as hercynian muscovites. Some detrital grains exhibit a zonation in Nacontent decreasing from core to rim (see H2 in fig. 6a). The Phengite-Quartz-Water method shows a decrease in the estimated temperature correlated with a decrease in Na-content $(\mathrm{H} 1$ and $\mathrm{H} 2$ groups in Fig. 10a). This zoning indicates that hercynian muscovites crystallised during cooling (hercynian exhumation). Micas belonging to the A group have higher Sicontents (above $3.25 \mathrm{pfu}$ ) and are identified as alpine phengites. Well-developed phengites are zoned and exhibit a decrease in their Si content from core to rim (see A1g1 core in fig. $6 b)$. This result shows that A phengites crystallized during the alpine retrogression path under decreasing pressure conditions. This zonation is confirmed by the Phengite-Quartz-Water 
method, which shows a decrease in estimated pressures for a fixed temperature (close to $260^{\circ} \mathrm{C}$ ) between $\mathrm{A} 1 \mathrm{~g} 1$ and A1g2 mica groups.

\section{Chlorites:}

Similarly to mica, flakes of detrital chlorite are easily identified using microstructural criteria. They are preferentially re-oriented in the S1 schistosity and kinked (H1 in fig. 7). Chlorite also shows chemical variations (Fig 7 and 9). $\mathrm{H} 1$ and $\mathrm{H} 2$ chlorites show higher (Mg $+\mathrm{Fe}$ )-contents than $\mathrm{A} 1$ and $\mathrm{A} 2$ chlorite. Both $\mathrm{H} 1$ and $\mathrm{H} 2$ chlorites have high $\mathrm{Al}^{\mathrm{IV}}$ contents ranging from 1.2 to $1.4 \mathrm{pfu}$, and they present a zonation with decreasing $\mathrm{Mg}$ from core to rim. The separation in two groups $\mathrm{H} 1$ and $\mathrm{H} 2$ is based on the $\mathrm{Mg}$ and $\mathrm{Fe}$ variations. Indeed, from core to rim, $\mathrm{H}$ chlorites exhibit a decrease of the $(\mathrm{Mg}+\mathrm{Fe})$ content (Tab. 3 and Fig. 7). The A1 and A2 chlorites are poorer in $\mathrm{Mg}$ (1.2 pfu) and show a decrease in Fe-content from $2.3 \mathrm{pfu}$ for A1 (dark triangles in Fig. 9b) to 1.9 pfu for A2 (circles in Fig. 9b).

The Chlorite-Quartz-Water method of Vidal et al. $(2005 ; 2006)$ has been applied to all pixels of chlorite groups $(\mathrm{H} 1, \mathrm{H} 2, \mathrm{~A} 1, \mathrm{~A} 2)$ from the X-Ray map. The results for representative analyses of the $\mathrm{A} 1, \mathrm{~A} 2, \mathrm{H} 1$ and $\mathrm{H} 2$ compositions are listed in Table 3. Temperature estimates for $\mathrm{H} 1$ and $\mathrm{H} 2$ chlorites range between $360-390^{\circ} \mathrm{C}$ and $300-360^{\circ} \mathrm{C}$, respectively. In contrast, $\mathrm{A} 1$ and $\mathrm{A} 2$ chlorites show lower temperatures ranging from $300^{\circ} \mathrm{C}$ to $100^{\circ} \mathrm{C}$ (Fig. 10b). Some A chlorites exhibit a decrease of the Fe-content from core to rim associated to a temperature decrease (between A1 and A2 groups). These variations allow displaying the $260^{\circ} \mathrm{C}$ isograd in the Fe-Mg chemical space. Temperatures of the Si-richest chlorites $(\mathrm{Si}>3 \mathrm{pfu}$ ) could not be calculated with the solid-solution model of Vidal et al. (2006), which is relevant for chlorite with $\mathrm{Si}<3$ only. For these compositions, the temperatures were estimated with the chlorite thermometer of Inoue et al. (2009), for $\left(\mathrm{XFe}^{3+}\right)_{\text {chlorite }} 0.25$. This value was inferred from the $\mathrm{T}-\mathrm{XFe}^{3+}$ evolution calculated for the higher temperature chlorite with the approach of Vidal et al. $(2005 ; 2006)$.

\section{3) P-T estimates:}

$\mathrm{P}-\mathrm{T}$ conditions were estimated from the intersection of the Mica-Qtz-H2O (Fig. 10a) and Chl-Qtz-H2O (Fig. 10b) equilibria. H1 and $\mathrm{H} 2$ phyllosilicates yield metamorphic conditions at $371 \pm 26^{\circ} \mathrm{C}, 3.5 \pm 1.4 \mathrm{kbar}$ and $326 \pm 19^{\circ} \mathrm{C}$ and $3.2 \pm 1.1 \mathrm{kbar}$, respectively (Fig. 11a). The equilibrium conditions of the Alpine assemblage A1g1 and A2g1 were estimated at $275 \pm 23^{\circ} \mathrm{C}, 5.9 \pm 1.7 \mathrm{kbar}$ and $260 \pm 18^{\circ} \mathrm{C}, 2 \pm 1.2 \mathrm{kbar}$, respectively (Fig. 11b). Late chlorites with high Si-content ( $>3 \mathrm{pfu}$ ) crystallized at lower temperature between $200^{\circ} \mathrm{C}$ and $100^{\circ} \mathrm{C}$. Assuming a geothermal gradient of $40^{\circ} \mathrm{C} / \mathrm{km}$ (see discussion), the pressure conditions at such temperature is less than 2 kbar. The combination of these results pleads for an early and rapid isothermal exhumation stage followed by a later stage of slow and almost isothermal exhumation.

\section{6) Discussion:}

\section{1) Characterization of hercynian and alpine metamorphic conditions:}

Microstructural criteria and chemical analyses, associated with thermodynamic modelling, point out distinctions between $\mathrm{A}(\mathrm{A} 1+\mathrm{A} 2)$ and $\mathrm{H}(\mathrm{H} 1+\mathrm{H} 2)$ metamorphic minerals (Fig. 8, for K-white mica and Fig. 9, for chlorite). P-T conditions are associated with specific mineral chemistries such as low Si-content in $\mathrm{H}$ muscovites and high $\mathrm{Mg}$-content in $\mathrm{H}$ chlorites. A retrogressive path is evidenced using mineral zoning, starting at a metamorphic peak of $371 \pm 26^{\circ} \mathrm{C}$ and $3.5 \pm 1.4$ kbar (Fig. 11a). H minerals are detrital minerals deposited 
in sandstone levels of the Carboniferous basins during erosion of the hercynian metamorphic belt. Part of the detrital phyllosilicates is preserved during the alpine metamorphic overprint, while new phyllosilicates crystallized. The high $\mathrm{Si}^{4+}$ content in phengites cores (A1g1 in Fig. 6b) constitutes an argument to propose HP-LT peak conditions at $275 \pm 23^{\circ} \mathrm{C}$ and $5.9 \pm 1.7$ kbar (Fig. 11b). A (A1+A2) phengites are interpreted as related to Alpine metamorphism. Alpine metamorphic conditions peak calculated for the upper houiller unit $\left(275^{\circ} \mathrm{C}\right.$ and 6 kbar) are consistent with the presence of lawsonite as described by Fabre et al. (1982).

\section{2) Identification of two types of $\mathrm{CM}$ in the Briançonnais Zone houillère:}

Two methods have been used depending on the type of CM: that of Beyssac et al. (2002) for high temperatures $\left(>330^{\circ} \mathrm{C}\right)$ and that of Lahfid et al. (2010) for low temperatures $\left(<330^{\circ} \mathrm{C}\right)$. In our case, this point merits a specific discussion. Both types of $\mathrm{CM}$ occur in the same sample based on the shape of the spectra and the microstructural location (fig. 4). As previously underlined, muscovites are Hercynian and record higher-temperature metamorphism compared to the alpine metamorphic phengites. The CM preserved as inclusions in detrital minerals (muscovite and $\mathrm{Mg}$-rich chlorite) record a hercynian hightemperature $\mathrm{T}_{\max }$ above $330^{\circ} \mathrm{C}$. In spite of the small number of analyses $(n=3)$, the $\mathrm{T}_{\max }$ of $390^{\circ} \mathrm{C}$ has a low dispersion $\left(1 \sigma=4^{\circ} \mathrm{C}\right)$. Moreover, this estimate of $\mathrm{T}_{\max }$ is consistent with the thermodynamic modelling results on $\mathrm{H}$ muscovite. The estimated temperature peak using $\mathrm{Mg}$-rich chlorite and muscovite is $371 \pm 26^{\circ} \mathrm{C}$. Using the intrinsic $\mathrm{T}_{\max }$ uncertainty to $50^{\circ} \mathrm{C}$ provided by Beyssac et al. (2002), the RSCM result is of $390^{\circ} \mathrm{C}+/-50^{\circ} \mathrm{C}$. Both results are in accordance and provide a range for the location of the Hercynian metamorphic peak between $350^{\circ} \mathrm{C}$ and $400^{\circ} \mathrm{C}$. It is important to note that we also found 3 high-temperature $\mathrm{CM}$ spectra in organic-rich schist samples. Their $\mathrm{T}_{\max }$ are identical and close to $390^{\circ} \mathrm{C}$. Thus, "detrital" $\mathrm{CM}$, recording HT metamorphism is present in small amounts $(<1 \%)$ in organic-rich schists. This last observation confirms that the different spectra reflect true $\mathrm{T}_{\max }$ differences related to two distinct metamorphic events.

The second type of CM is located in a different microstructural position. It consists of framboidal aggregates that were always analysed through transparent minerals. In this case, the spectra shape is characteristic of temperatures below $330^{\circ} \mathrm{C}$ (fig. 4a). We used the correlation observed by Lahfid et al. (2010) to estimate $\mathrm{T}_{\max }$ lower than $310^{\circ} \mathrm{C}$ in the Briançonnais Zone houillère. In contrast to the previous case, this low- $\mathrm{T}_{\max } \mathrm{CM}$ dominates in both organic-rich schist and sandstone lithologies (99\% of CM in organic-rich schists). As the $\mathrm{CM}$ in the organic-rich schist deposits is preserved in Carboniferous basins, they did not record the strong late hercynian thermal event (Frey et al., 1999), thus this $T_{\max }$ must necessary be Alpine in age. In the Chardonnet sector, the two analysed samples provide similar $\mathrm{T}_{\max }\left(296 \pm 3^{\circ} \mathrm{C}\right.$, see tab. 2). The same trend is observed in the Cula sector, with a slight variation of $4^{\circ} \mathrm{C}$ between both samples (tab. 2). In the Laval sector, the average $T_{\max }$ is $283^{\circ} \mathrm{C}$. The main conclusion is that the alpine $T_{\max }$ in the Briançonnais Zone houillère is nearly constant along our section.

\section{3) P-T-t contraints in the Briançonnais Zone}

The new estimates of Alpine peak metamorphic conditions at $275 \pm 23^{\circ} \mathrm{C}$ and $5.9 \pm$ 1.7 kbar complement the available data along this transect. Previous work has provided P-T estimates for the most internal Briançonnais zone (Ganne et al., 2003; Ganne et al., 2007; Gerber 2008; Strzerzynski et al., this issue). In the Briançonnais stack of sedimentary cover thrust sheets, the metamorphic peak was reached at $12 \mathrm{kbar}$ and $300^{\circ} \mathrm{C}$ (Gerber, 2008), while 
estimates for the Ambin basement sugget 15-18 kbar and $500^{\circ} \mathrm{C}$ (Ganne et al., 2007; Gerber, 2008).

The absolute age of D1 was constrained throughout the Briançonnais zone by stepheating and laser ablation dating on K-white mica (Ganne, 2003; Berger \& Bousquet, 2008; Gerber, 2008). The measured ages show a wide range between 40 and $55 \mathrm{Ma}$ with a peak at ca. $50 \mathrm{Ma}$ for the internal parts of the Zone briançonnaise. This age-range reflects the crystalchemical zonation of the micas. The age of $\mathrm{D} 2$, associated with west-verging kinematics is better constrained ranging between $37 \mathrm{Ma}$ and $32 \mathrm{Ma}$ (Ganne et et al., 2007; Strzerzynski et al., this issue). Other estimates on associated shear zones further north (Entrelor Shear Zone) indicated similar ages (Freeman et al., 1997). The D2 ages are interpreted as the youngest limit for greenschist facies metamorphism (Ganne et al., 2007). This event occurred at lowpressure conditions and is associated with a decrease of both pressure and temperature, indicating a relatively low exhumation rate. The end of the metamorphic evolution is constrained by Apatite Fission Track (AFT) analysis. In the Briançonnais Zone houillère, AFT ages decrease from 27 - 32 Ma near Briançon (Tricart et al., 2007 and references therein) to $18 \mathrm{Ma}$ in the northern part in the Arc Valley (Fugenschuh and Schmid, 2003; Malusà et al., 2005), and 8-10 Ma in southern Aosta Valley, to $6 \mathrm{Ma}$ in the northern Aosta Valley (Malusà \& Vezzoli 2006). This south to north younging of ages suggests that exhumation was partitioned in the Briançonnais Zone houillère. In the studied sector, AFT ages are comparatively old (up to $31.7 \mathrm{Ma}$ ) indicating final exhumation since the onset of the so-called "collision phase". The transition between continental subduction and collision is characterized by the underthrusting of european continental crust below the propagating penninic thrust from 34 to 28 Ma (Sanchez et al., 2011; Simon-Labric et al., 2009). Considering the east-west transect studied here, variations in AFT ages also suggest an eastwest diachronic exhumation. The Ambin basement is well documented with AFT ages between 18 and $23 \mathrm{Ma}$ (see Tricart et al., 2007 for references). The Schistes lustrés display general east-west younging AFT ages between 22 and 9 Ma (Schwartz et al., 2007). The studied transect between the Briançonnais Zone houillère and the Dora Maira massif displays an eastward decrease in AFT ages from $30 \mathrm{Ma}$ in the Briançonnais Zone houillère to $22 \mathrm{Ma}$ in the eastern part of the Schistes lustrés, $19 \mathrm{Ma}$ in the Ambin basement, and $9 \mathrm{Ma}$ in the Monviso units. These observations indicate that final exhumation is strongly diachronous along our transect in the internal zones, and migrates from west to east during OligoceneMiocene times.

\section{times:}

\section{4) Geodynamic model for the Briançonnais Zone during Eocene-Oligocene}

A possible kinematic reconstruction of this part of the western Alps during EoceneOligocene times (between 50 and $30 \mathrm{Ma}$ ) is proposed in Fig. 12. During the 50 - $45 \mathrm{Ma}$ time interval peak P-T conditions were reached in both the Ambin basement and Vanoise cover at depths between 40 and $60 \mathrm{~km}$. At that time, the Briançonnais Zone houillère was not yet involved in the continental subduction. Peak pressure conditions were established in the Schistes lustrés complex before 62-55 Ma (Agard et al., 2002). At $50 \mathrm{Ma}$, the Schistes lustrés units were already partly exhumed (see Agard et al., 2001). Note that P-T estimates in the Schistes lustrés for this event (D2 in Agard et al., 2001) show a metamorphic gradient consistent with the gradient in the Briançonnais zone of $8-10^{\circ} \mathrm{C} / \mathrm{km}$.

In the 40-37 Ma time interval, the Ambin basement and Vanoise cover units were exhumed from 18 and $24 \mathrm{~km}$ depths, respectively. At the same time, the Briançonnais Zone 
houillère reached P-T peak conditions of $6 \mathrm{kbar}$ and $275^{\circ} \mathrm{C}$. The geothermal gradient was higher than $15^{\circ} \mathrm{C} / \mathrm{km}$, resulting from crustal thickening and lower convergence rates (Handy et al., 2010). The frontal thrust moved to the west with activation of the Briançonnais frontal thrust (D1 event in the Briançonnais Zone Houillère, Fig. 3). The Drayère shear zone was also active and drove the exhumation of the upper houiller unit.

The final stage in our reconstruction has been drawn for early Oligocene time (34-30 Ma in Fig. 12). The exhumation rate was very rapid in the Briançonnais zone, as illustrated by AFT ages close to $30 \mathrm{Ma}$. This exhumation, related to the Briançonnais front activity that involves the underthrusting of the Pelvoux by crustal thickening (Simon-Labric et al., 2009), was associated with a high erosion rate. Doming of the briançonnais basement accompanied the top-to-the-east movement observed in the upper houiller unit. It is probably during this event (D2 in the upper Houiller unit, Fig. 3) that westward tilting of the Drayère shear zone took place and that the Briançonnais zone acquired its fan structure. All units recorded P-T conditions along a metamorphic collisional gradient of $40^{\circ} \mathrm{C} / \mathrm{km}$. This view is compatible with AFT ages that display diachronous exhumation across the belt. At $30 \mathrm{Ma}$, exhumation was almost ended in the Briançonnais Zone houillère, but not in the innermost parts of the Alpine belt (Ambin, Monviso areas).

This kinematic reconstruction implies a crustal segmentation into small thrust sheets during exhumation of continental bodies. P-T paths of each unit exhibit, as discussed above, diachronous burial and exhumation processes. The edification of this continental wedge requires small-size units with a width less than $30 \mathrm{~km}$. In contrast to results from Young et al. (2007) in Norway, this study highlights that the continental crust cannot remain coherent during metamorphism and exhumation in the Alps.

\section{terrains: \\ 6.5) Multi-method approach for P-T estimates in low-grade metamorphic}

This study shows that a detailed metamorphic analysis of low-grade metamorphic terrains can be conducted using the presented multi-method approach. Combining large-scale $\mathrm{T}_{\max }$ estimates from RSCM thermometry and local P-T estimate from chemical mapping and quantitative thermometry enables distinguishing between hercynian and alpine metamorphic events. Use of quantitative chemical mapping is essential to obtain a large number of analyses and to identify chemical zoning. Distinguishing between detrital and newly grown metamorphic minerals is not possible using conventional methods such as optical microscopy. Partial recrystallization occurs by solid-state diffusion and recrystallization processes in such P-T conditions in the presence of metamorphic fluids (see Putnis \& Austrheim, 2010 and references therein). P-T estimates were realized using the multiequilibrium thermodynamic approach based on available solid solution models (Vidal et al., 2005; 2006; Dubacq et al., 2010). In contrast to pseudosections used for higher metamorphic conditions, these methods do not required knowledge of bulk rock composition. Nevertheless, the composition of recrystallized chlorites and phengites are strongly dependent on the bulk rock and the fluid composition (work in progress), therefore the chemical diagrams provided here cannot be easily transposed to other examples.

This study is also an example of a comparison between RSCM thermometry and multi-equilibrium techniques. Resulting estimates of the thermal peak are consistent between both methods for the alpine and hercynian metamorphic events. 


\section{7) Conclusion:}

In this contribution, a multi-method approach was used to quantify $\mathrm{P}$ and $\mathrm{T}$ conditions in a low-grade metamorphic terrain: the Briançonnais Zone houillère. Quantified microprobe maps associated with thermodynamic modelling allowed distinguishing, in the same sample, alpine metamorphic chlorite and phengite (A minerals) and hercynian derived detrital chlorite and muscovite ( $\mathrm{H}$ minerals). This study reports the first quantification of metamorphic conditions recorded by detrital minerals and newly grown minerals in the same composite texture of a metasedimentary rock. This study highlights the importance of the use of phengite and chlorite minerals to derive P-T paths in different metamorphic domains, even at very low temperatures. P-T results show convincing correlations between RSCM thermometry and thermodynamic analysis and provided P-T estimates of the alpine metamorphic peak of $275 \pm 23^{\circ} \mathrm{C}$ and $5.9 \pm 1.7 \mathrm{kbar}$ in the upper Houiller unit. Our $\mathrm{T}_{\max }$ estimates between $275^{\circ} \mathrm{C}$ and $300^{\circ} \mathrm{C}$ are compatible with ZFT data available in the lower Houiller unit further north. This thermal shape likely results form a top-to-the-NW D1 thrusting event. The subsequent D2 event is associated with a top-to-the-east shearing and "backtrusting" of the Briançonnais zone onto the Piedmont Schistes lustrés. In contrast, the H minerals show that Hercynian peak conditions were hotter at $371 \pm 26^{\circ} \mathrm{C}$ and $3.5 \pm 1.4 \mathrm{kbar}$.

These data give rise to a refined geodynamic model of this alpine transect during Eocene-Oligocene times. The results clearly show diachronous burial and exhumation dynamics for different parts of the Briançonnais Zone, which highlights the complexity evolution of the continental wedge. This study clearly shows a segmentation of crustal units into relatively small thrust sheets, contrary to some models arguing for large-scale exhumation (e.g. Young et al., 2007). 


\section{Acknowledgments:}

Authors would like to sincerely thank G. Gosso (University of Milano) and an anonymous reviewer for their helpful comments, J.M. Lardeaux (University of Nice) and R. Stephenson (University of Aberdeen) for efficient editorial handling. We acknowledge contributions of other members of the Grenoble ISTerre lab and especially: Mathias Bernet, Peter van der Beek, Emilie Janots, Thierry Dumont, Arnaud Pêcher. We warmly thank F. Couffignal (CAMPARIS) for EPMA facilities access and help, B. Dubacq (University of Cambridge) for thermodynamic help and Peter van der Beek (ISTerre) for English corrections. The Raman microspectrometer at IMPMC Paris has been funded by the ANR JCJC program (project GeoCARBONS, PI O. Beyssac). This work was funded by the ERDAlps ANR project. 


\section{Figure captions:}

Figure 1: Geological map of (a) the western Alps; (b) The Briançonnais zone between the Pelvoux and Ambin massifs (modified after Barféty et al., 2006a; Ford et al. 2006; Gabalda, 2008 and Gabalda et al. 2009). RSCM $\mathrm{T}_{\max }$ estimates in the Briançonnais Zone houillère from this study and Gabalda et al., 2009, are shown with an absolute incertitude of $+/-50^{\circ} \mathrm{C}$. Symbols refer to the stratigraphic unit (square for the upper houiller unit and circle for the lower houiller unit). PF: Penninic Front; EHF: External Houiller Front; DSZ: Drayere Shear Zone; IHF: Internal Houiller Front; SLF: Schistes lustrés Front. Am: Ambin; Pe: Pelvoux; Va: Vanoise. The detailed map (b) is located in the sketch map (a).

Figure 2: Simplified geological map of the Clarée valley area modified after Fabre (1982) and Fabre et al. (1982). All samples used in the RSCM study (squares) and for P-T estimations based on X-ray mapping (star) are located in the map. This study is confined to the Namurian-Stephanian formations. DSZ, Drayères Shear Zone.

Figure 3: Structural cross-section across the external and internal zones of the western Alps (A-A' section in Fig. 1), north of Briançon modified after Fabre et al. (1982); Caby et al. (1996); Barféty et al. (2006a, 2006b). Note the fan-shape structure of the Briançonnais zone. Fault movements are indicated with the associated tectonic phase (1 or 2). PF: Penninic Front; EHF: External Houiller Front (corresponding here to the Briançonnais Front); DSZ: Drayere Shear Zone; IHF: Internal Houiller Front.

Figure 4: Selection of representative first-order region of Raman spectra from sample PL0874 sample (cf. table 2). (a) Low-temperature CM is microcrystal aggregates. Spectra exhibit low-temperature characteristics, such as the D4 shoulder around $1200 \mathrm{~cm}^{-1}$ [1] and a widely developed D3 band around $1500 \mathrm{~cm}^{-1}$ [2]. In this case the thermometer of Lahfid et al. (2010) has been used (see text). (b) High temperature CM in inclusion within muscovites. HT spectra exhibit a D2 band shoulder close to $1620 \mathrm{~cm}^{-1}$ indicating a large graphite band. In this case, the thermometer of Beyssac et al. (2002) has been used (see text).

Figure 5: Detailed cross-section of the Briançonnais houiller zone (upper and lower houiller unit) including RSCM T $\mathrm{T}_{\max }$ estimations using the method of Lahfid et al. (2010) (see text). Legend is the same as Fig. 3, and sectors refer to Fig. 2.

Figure 6: (a) Si-content (pfu) and (b) Na-content (pfu) compositional maps of K-white-micas from sample PL08-74. Mica types noted by arrows (H1, H2, A1 and A2) are discussed in the text.

Figure 7: (a) Al-content (pfu), (b) Mg-content in M2+M3 (pfu) and (c) Fe-content in M2+M3 (pfu) compositional maps of chlorites from sample PL08-74. Chlorite types noted by arrows (H1, H2, A1 and A2) are discussed in the text.

Figure 8: Chemical analysis of K-white micas in Na-Si space (pfu). (a) Density map of all micas analysis on the X-ray map. (b) Chemical evolutions for four groups of pixels selected manually on the map (see location in fig. 5) and plotted: gH1 (dark squares) Na-rich 
muscovites; gH2 (light squares) Na-intermediate muscovites; gA1g2 (dark triangles) Si-rich phengites and gA1g2 (light triangles) low-Si phengites. Representative analyse of each groups (K-white-micas: H1, H2, A1g1 and A1g2; grey diamonds) are listed in table 4.

Figure 9: Chemical analysis of chlorites in Fe-Mg space (pfu, considering the M2-M3 octahedral sites). (a) Density map of all chlorite analysis on the X-ray map. (b) Chemical evolutions for five groups selected manually on the map (see location in fig. 6): gH1 (dark squares) Hercynian chlorites, which have crystallization temperature above $360^{\circ} \mathrm{C}, \mathrm{gH} 2$ (light squares) Hercynian low-temperature Hercynian chlorites, between $300^{\circ} \mathrm{C}$ and $360^{\circ} \mathrm{C}, \mathrm{gA} 1 \mathrm{~g} 1$ (dark triangles) Alpines chlorites, which have crystallization temperature between $260^{\circ} \mathrm{C}$ and $300^{\circ} \mathrm{C}$, gA1g2 (light triangles), low-temperature Alpine chlorites, with temperatures between $200^{\circ} \mathrm{C}$ and $260^{\circ} \mathrm{C}$ and $\mathrm{gA} 2$ (dark circles), late chlorites, which have crystallization temperature below $200^{\circ} \mathrm{C}$. Representative analyse of each groups (Chlorites: H1, H2, A1g1, A1g2 and A2, grey diamonds) are listed in table 3.

Figure 10: (a) K-white-mica P-T estimatates (lines) using the method of Dubacq et al. (2010). Boxes are constructed using the results of the Chlorite thermometer (b). For a given temperature, pressure has been estimated along the corresponding K-white-mica P-T equilibrium lines. The deviation proposed (see text) is the maximum possibility in pressure and temperature to combine both methods. (b) Reconstruction of chlorite temperatures pseudo-distribution (without vertical scale) from histograms of each group.

Figure 11: P-T paths using P-T estimation of chlorites and $\mathrm{K}$-white-micas (boxes) and $\mathrm{T}_{\max }$ estimation using RSMC study (gradation). Her $\mathrm{T}_{\max }$ is the hercynian $\mathrm{T}_{\max }$ of $393 \mathrm{H} / \mathrm{-} 50^{\circ} \mathrm{C}$ obtained on included CM in sample PL08-74 using the method of Beyssac et al. (2002). Alp. $\mathrm{T}_{\max }$ is the Alpine $\mathrm{T}_{\max }$ obtained from CM in the sample PL08-74 using the method of Lahfid et al. (2010). Typical geothermal gradients of subduction $\left(8^{\circ} \mathrm{C} / \mathrm{km}\right)$ and collision $\left(40^{\circ} \mathrm{C} / \mathrm{km}\right)$ as well as an intermediate gradient $\left(15^{\circ} \mathrm{C} / \mathrm{km}\right)$ are also shown.

Figure 12: Possible kinematic reconstruction of this part of the Western Alps from Eocene to Oligocene (modified from Gabalda, 2008) with associated P-T paths for Ambin basement and Vanoise cover (Gerber, 2008, see text) and the Briançonnais Zone houillère (this study). The geometry of the accretionary prism is from geophysical investigations in a paleo-accretionary complex in the Chilean forearc (Glodny et al., 2005). Geothermal gradient of (a) $8^{\circ} \mathrm{C} / \mathrm{km}$, (b) $15^{\circ} \mathrm{C} / \mathrm{km}$ and (c) $40^{\circ} \mathrm{C} / \mathrm{km}$ are also shown.

Table 1: Correlation table showing the deformation history for both, faults and tectonic units. HF: Houiller Front; DSZ: Drayere shear zone.

Table 2: Samples and associated results using RSCM. longitude and Latitude are provided in Lambert II étendu. Results include the average and standard deviation of $\mathrm{n}$ spectra Ra1 area ratios of Lahfid et al. (2010). The $1 \sigma$ error is provided for each $\mathrm{T}_{\max }$ estimate and it must not exceed $8^{\circ} \mathrm{C}$ (Beyssac et al., 2007).

Table 3: Selection of quantified analysis and structural formulae of chlorites which location are indicated in fig. 6. Chlorites $\mathrm{H} 1, \mathrm{H} 2, \mathrm{~A} 1$ and $\mathrm{A} 2 \mathrm{~g} 1$ temperatures has been estimated using Chlorite-Quartz-Water thermometry for a given pressure of $4 \mathrm{kbar}$. X.Fe $\mathrm{Fe}^{3+}$ is estimated by the 
model and correspond to the minimum amount of $\mathrm{Fe}^{3+}$. A2g2 chlorite has high Si-content (Si $>3$ ) and temperature has been calculated using the thermometer of Inoue et al. (2009) with reasonable value of $\mathrm{Fe}^{3+}$ fixed.

Table 4: Selection of quantified analysis and structural formulas of mica, which location are indicated in figure 5. 


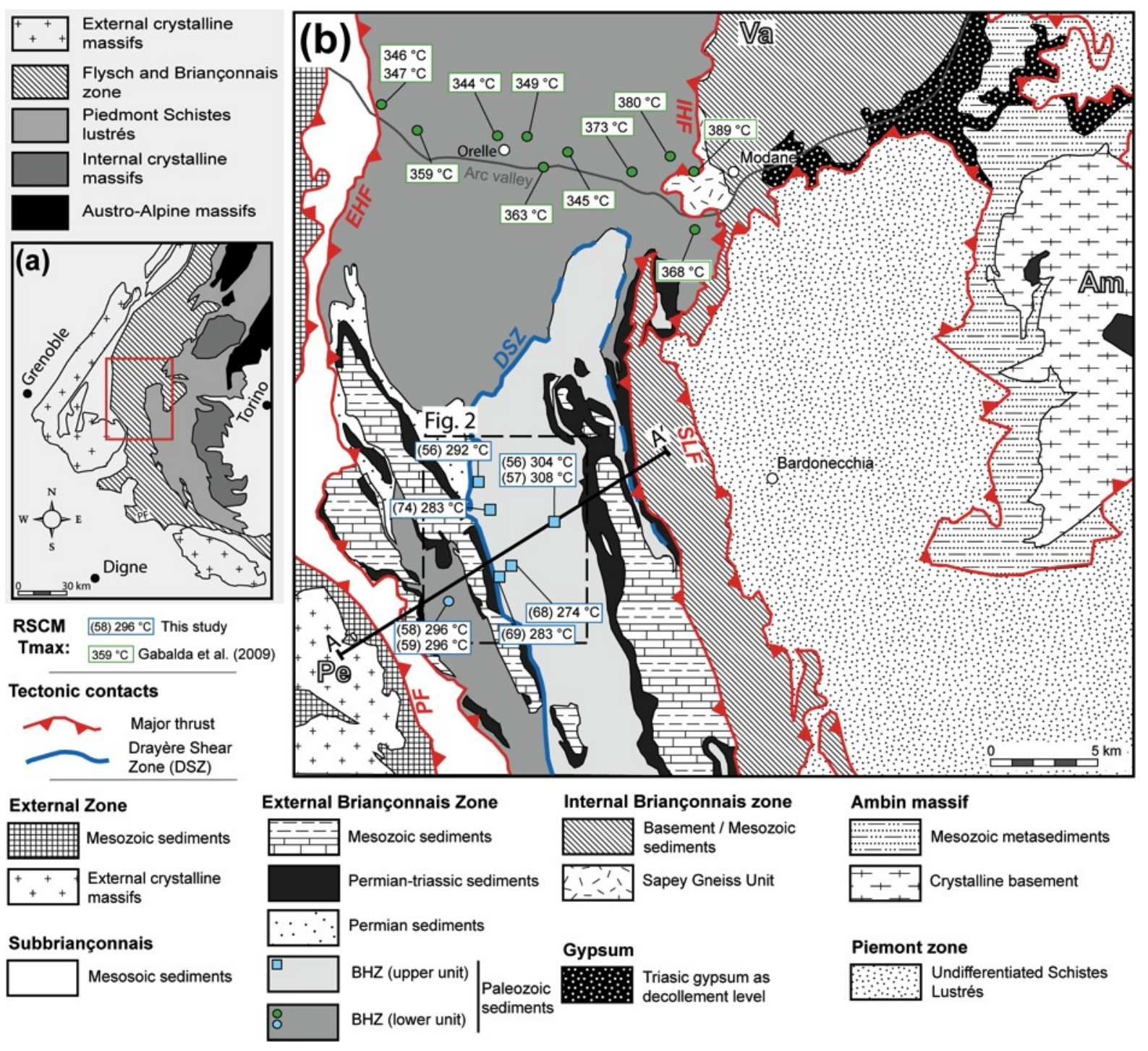

Figure 1 


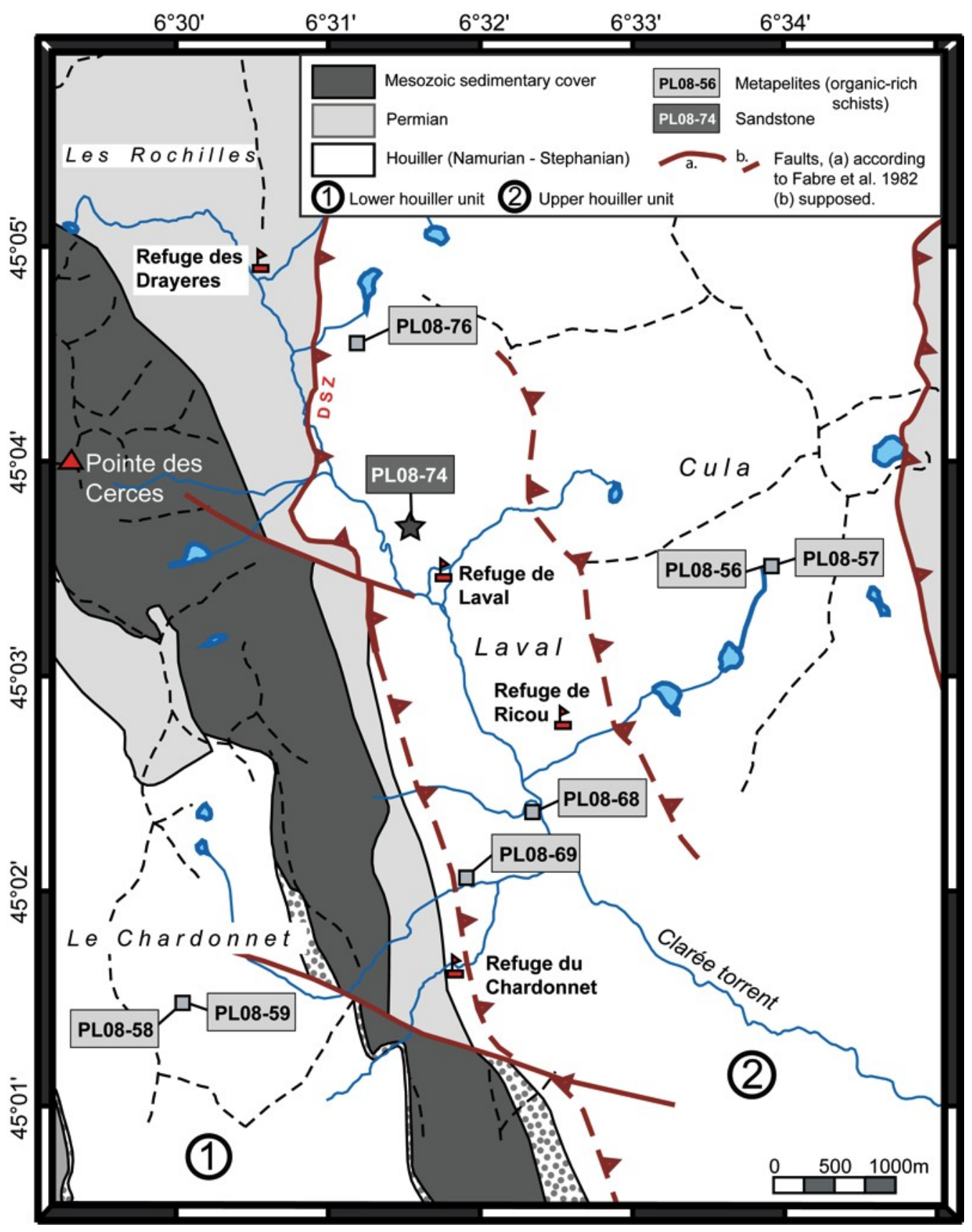

Figure 2 


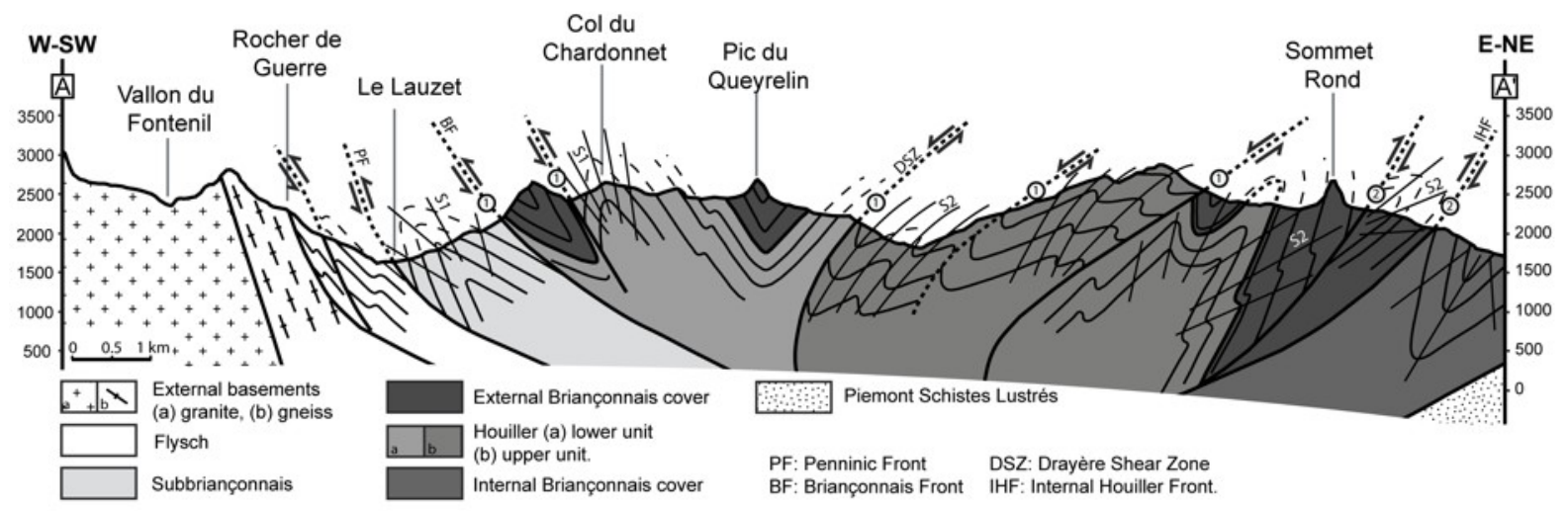

Figure 3

(a) Low temperature

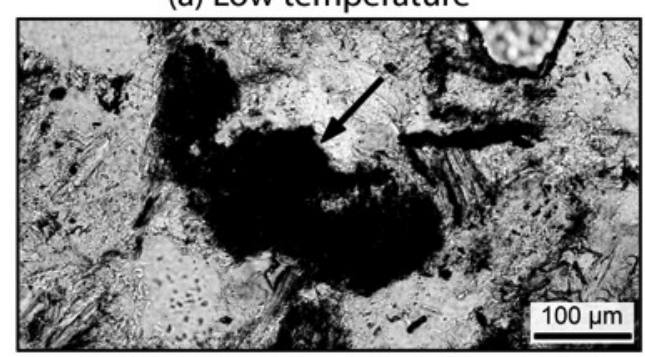

$\operatorname{Tmax}=283^{\circ} \mathrm{C}$

Lahfid et al., (2010)

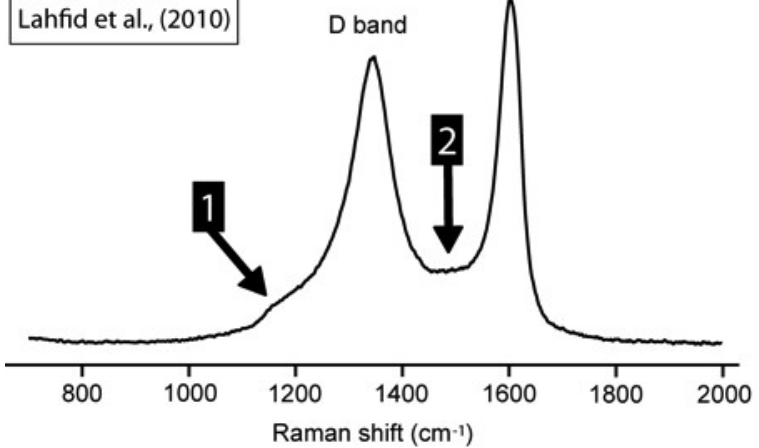

(b) high temperature
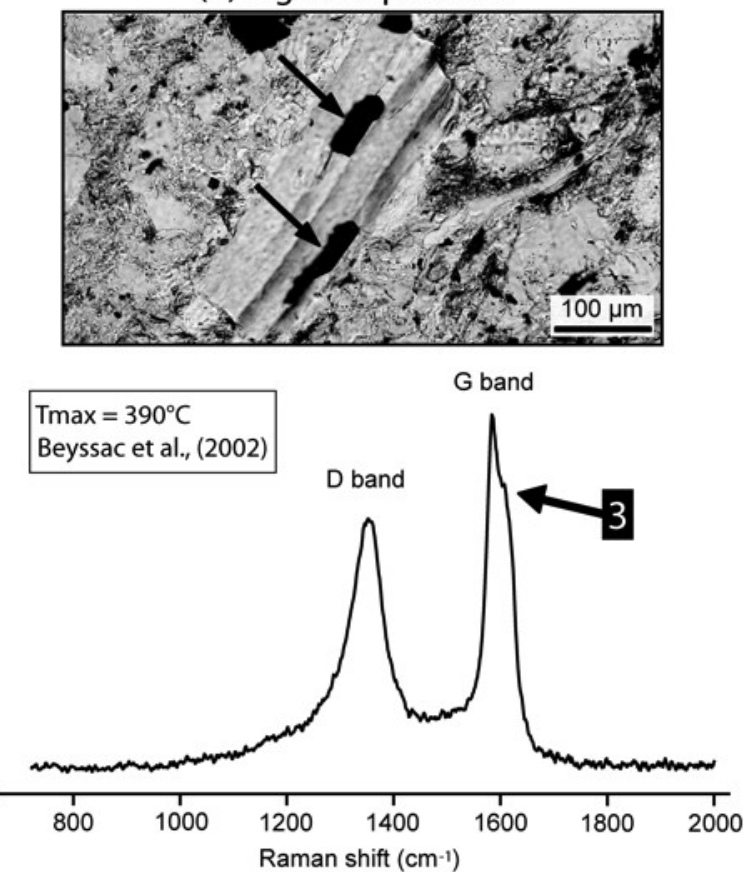

Figure 4 


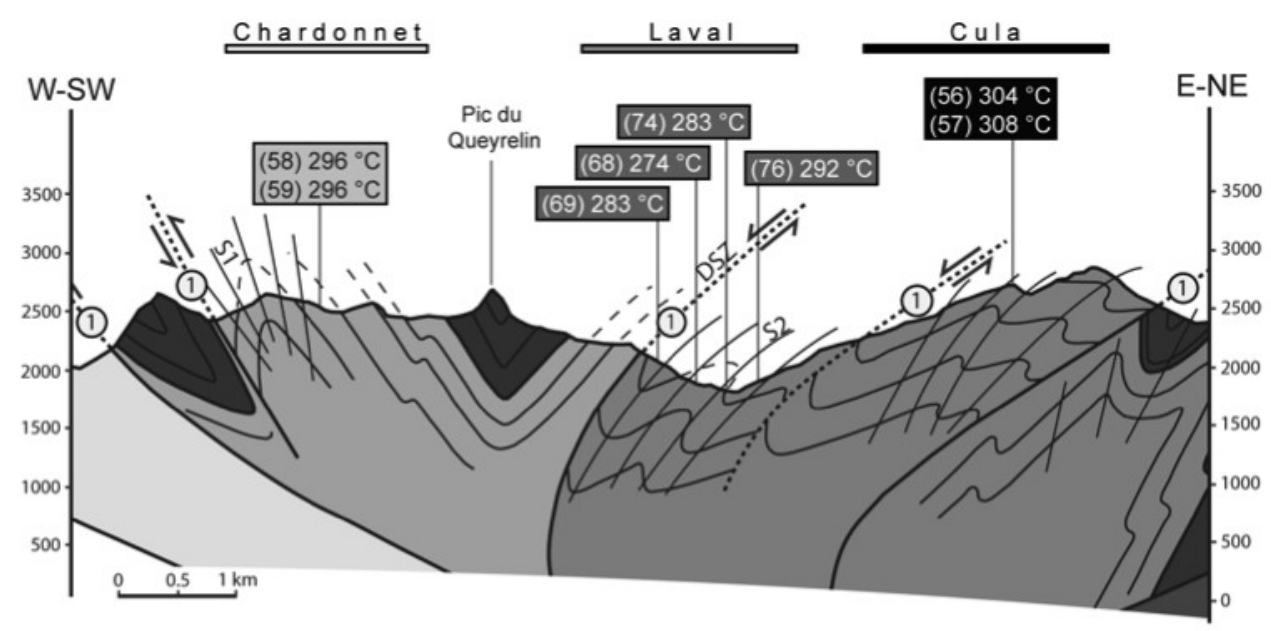

Figure 5
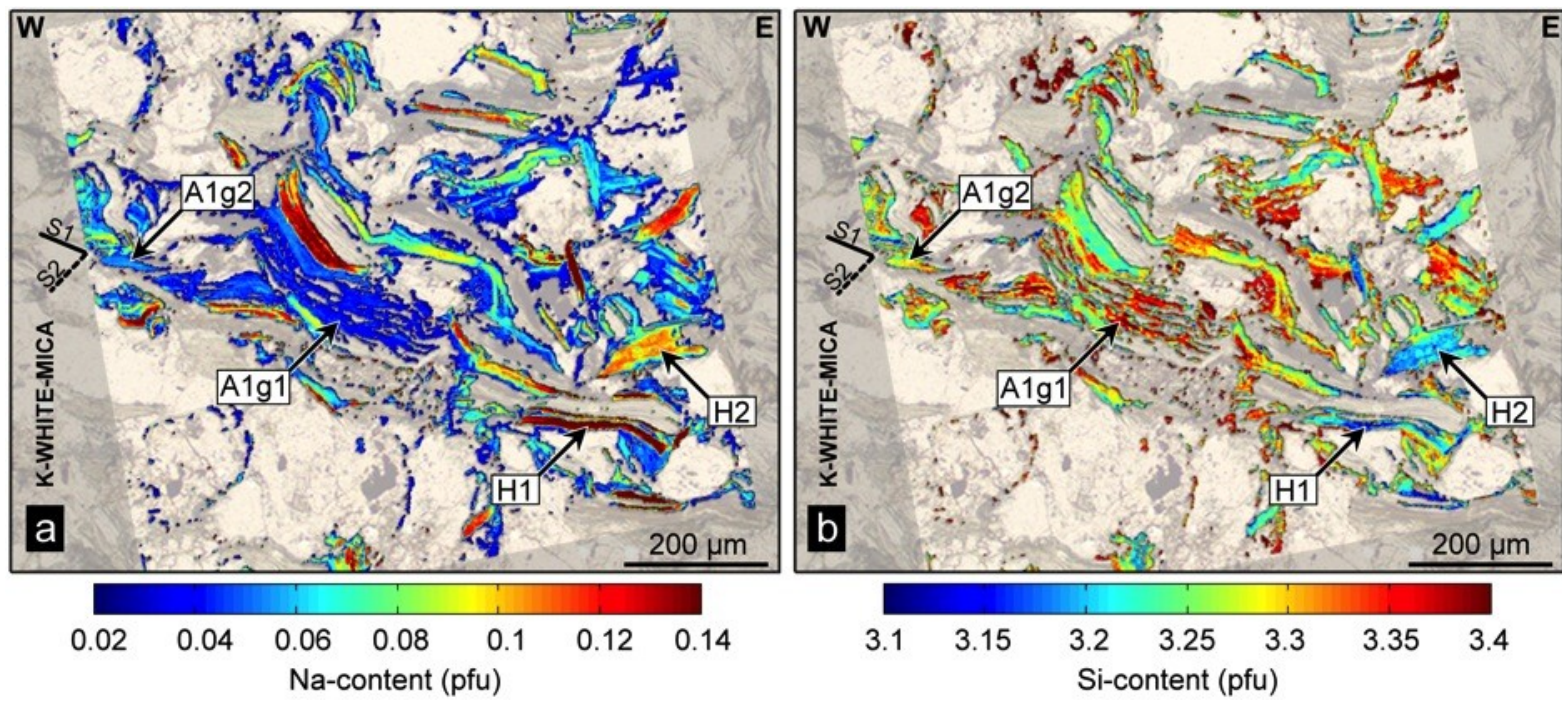

Figure 6 

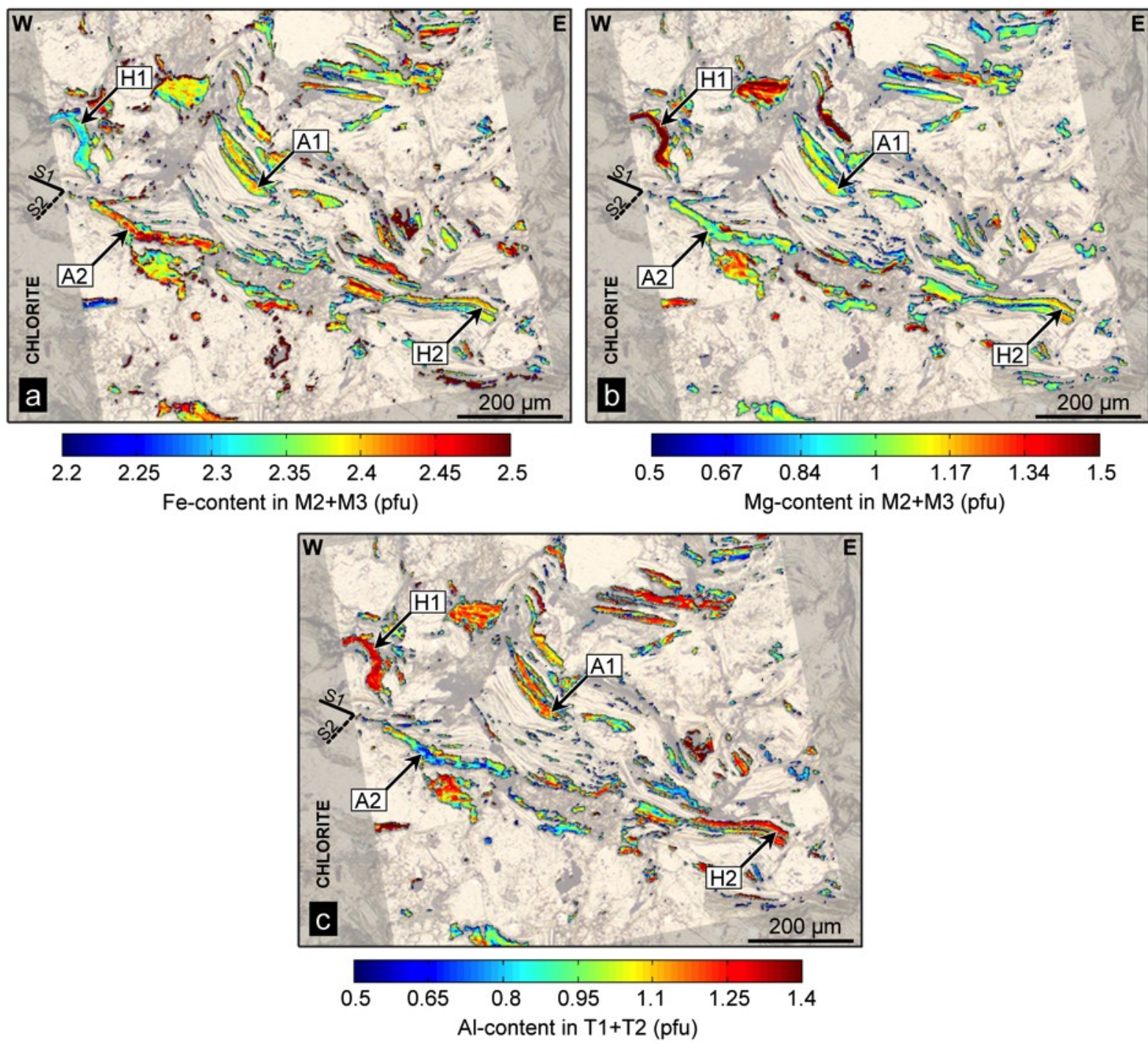

Figure 7 

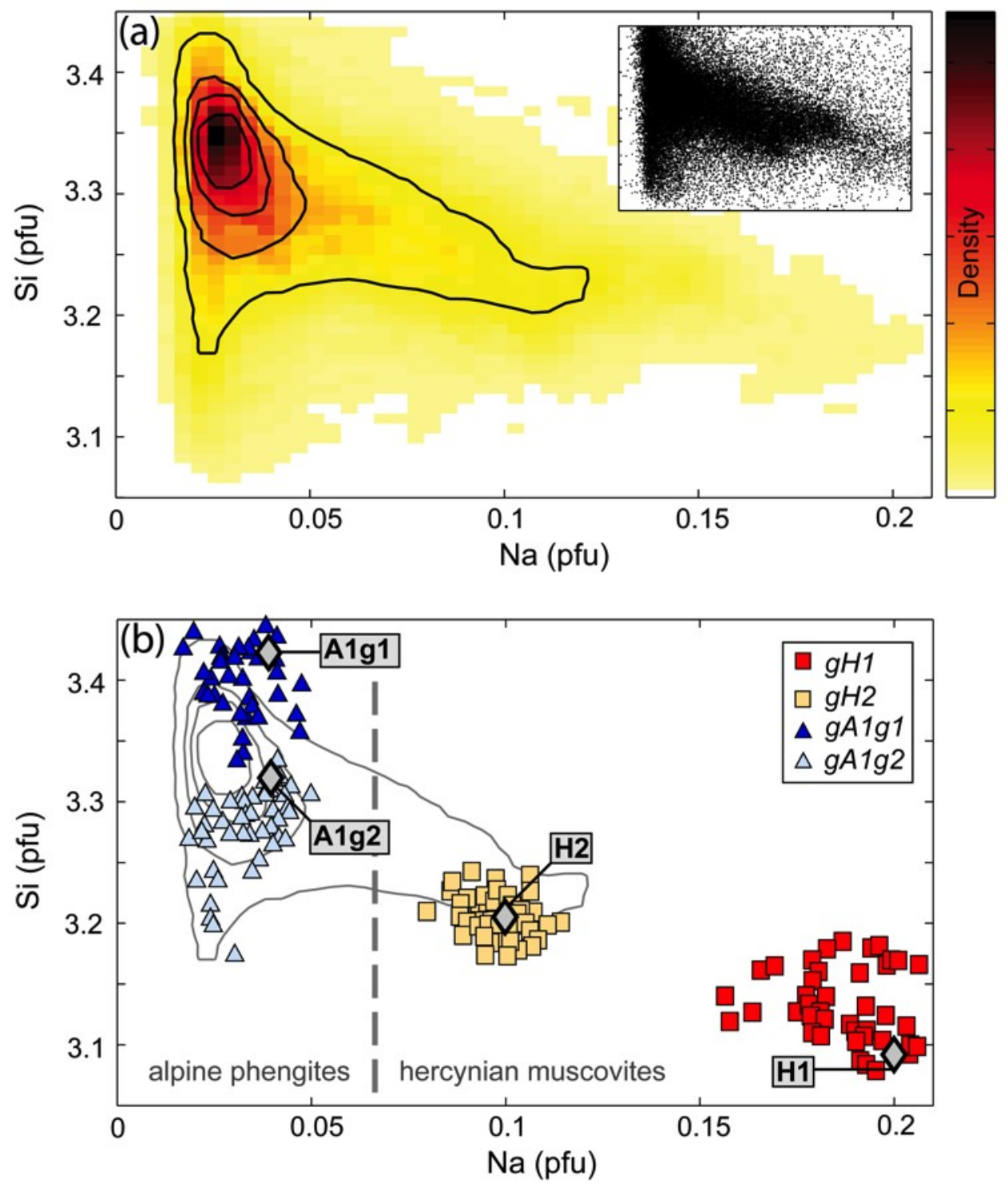

Figure 8 

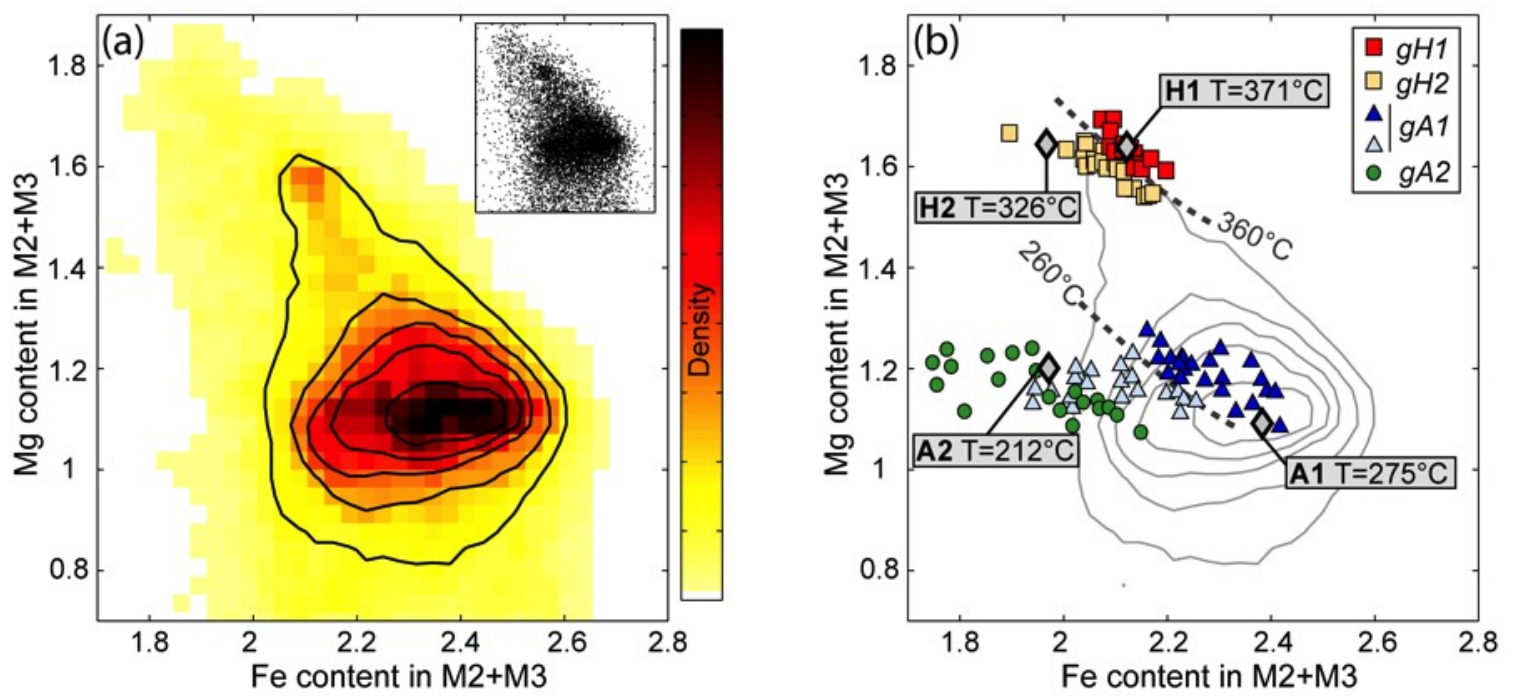

Figure 9
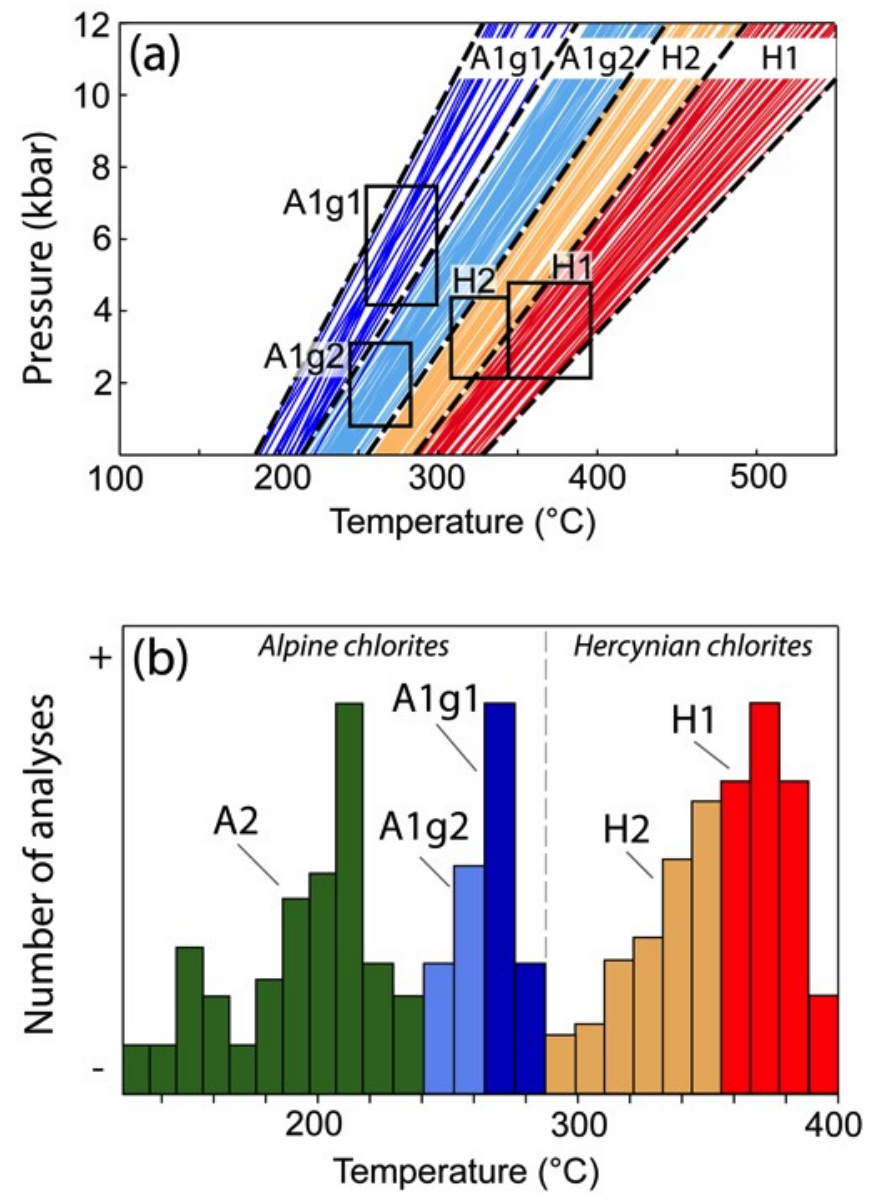

Figure 10 

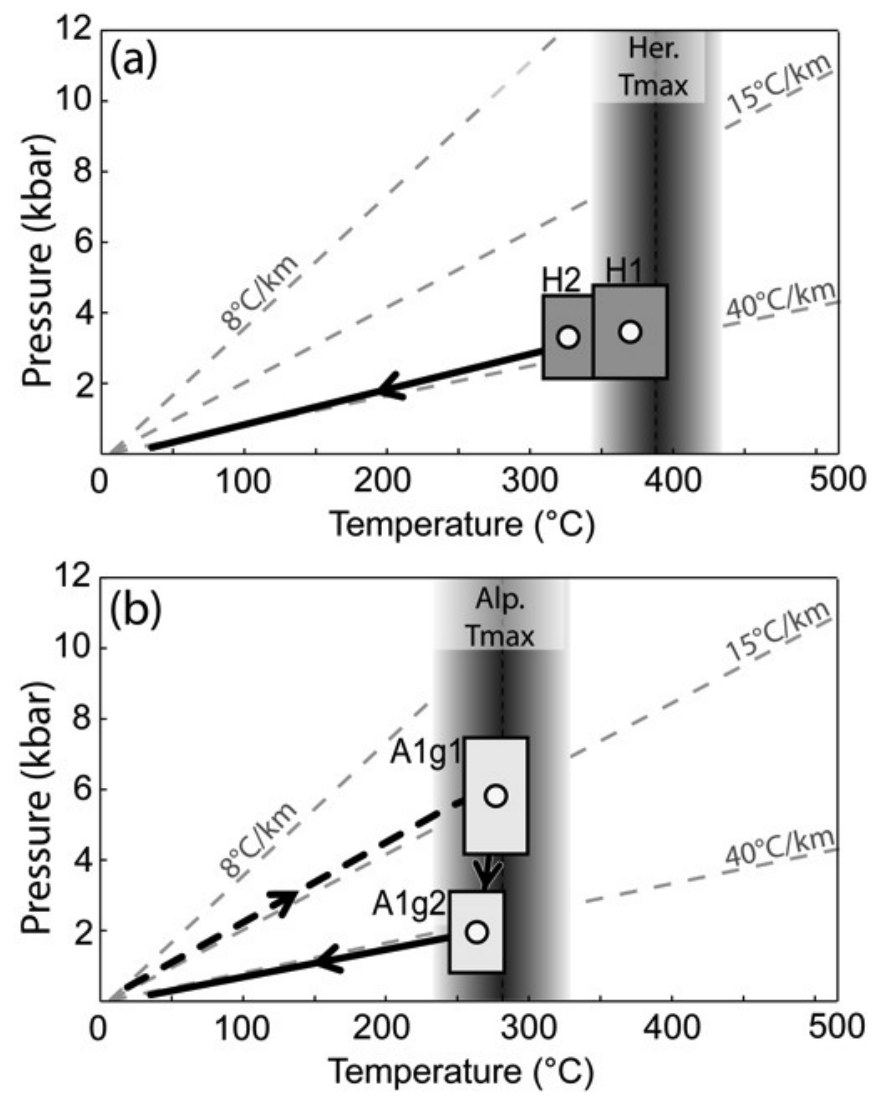

Figure 11 

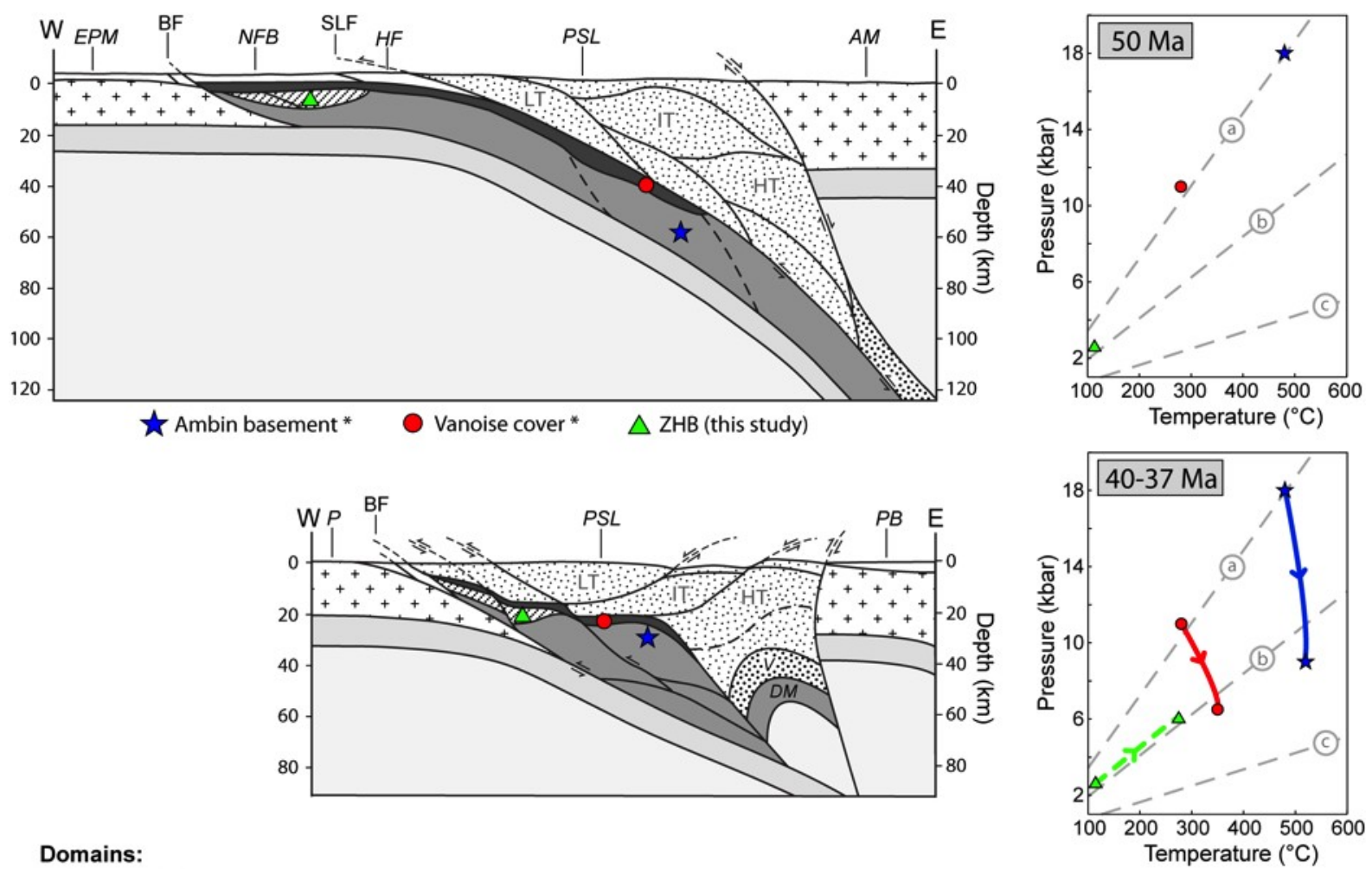

\section{AM: Apulian Margin}

$D M$ : Dora-Maira

EPM: European Passive Margin HF: Helminthoid Flysch nappes NFB: Nummulitic Foreland Basin $P$ : Pelvoux crystalline massif $P B$ : Po Basin

PSL: Piedmont Schistes Lustrés $V$ : Viso ophiolites

Tectonic contacts:

BF: Briançonnais Front

DSZ: Drayère Shear Zone

IBF: Internal Briançonnais Front

SLF: Schistes Lustrés Front
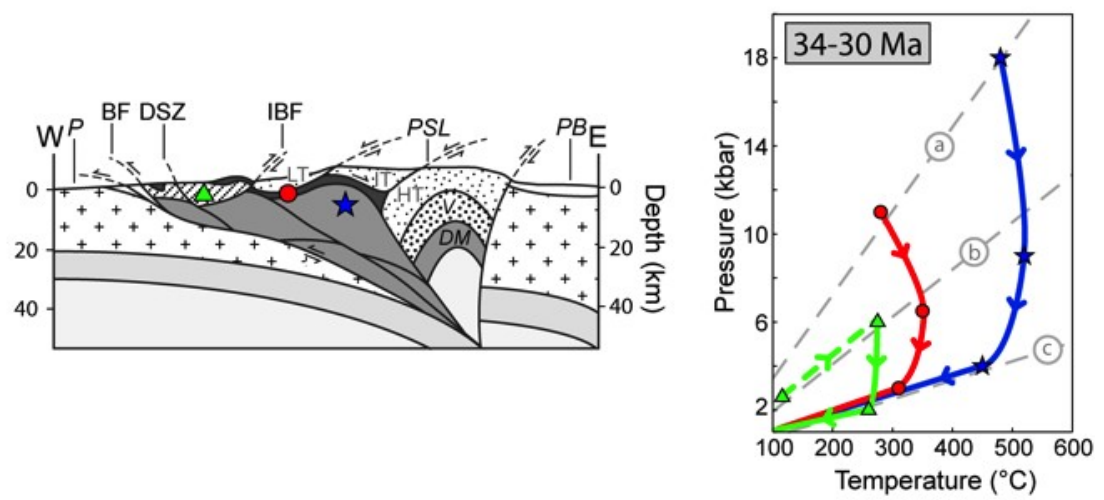

SL metamorphic units: LT (Low Temperature) IT (Intermediate Temperature) HT (High Temperature)

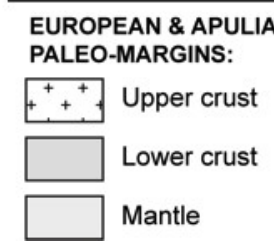

BRIANCONNAIS ZONE:

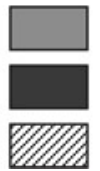

Basement

Sedimentary cover

Briançonnaise Zone houillère
OCEANIC UNITS:

Piemont Schistes lustrés
Viso ophiolites

Figure 12 


\begin{tabular}{|c|c|c|c|c|c|}
\hline & HF & $\begin{array}{l}\text { Lower Houiller } \\
\text { Unit (Bertrand } \\
\text { et al., 1996) }\end{array}$ & $\begin{array}{c}\text { Lower Houiller } \\
\text { Unit } \\
\text { (Chardonnet } \\
\text { Sector, this } \\
\text { study) }\end{array}$ & DSZ & $\begin{array}{c}\text { Upper Houiller } \\
\text { Unit (This } \\
\text { study) }\end{array}$ \\
\hline $\begin{array}{l}\text { D } \\
4\end{array}$ & & $\begin{array}{l}\text { Late extensional } \\
\text { stage }\end{array}$ & & & \\
\hline $\begin{array}{l}\mathbf{D} \\
\mathbf{3}\end{array}$ & & Km-size F3 folds & & & \\
\hline $\begin{array}{l}\mathbf{D} \\
2\end{array}$ & & $\begin{array}{l}\text { West-dipping S2 } \\
\text { schistosity and } \\
\text { recumbent F2 } \\
\text { folds facing } \\
\text { toward east. }\end{array}$ & $\begin{array}{l}\text { Large-scale } \\
\text { rotation }\end{array}$ & $\begin{array}{l}\text { Foldin } \\
\mathrm{g}\end{array}$ & $\begin{array}{l}\text { Km-size F2 folds } \\
\text { facing toward } \\
\text { east with axial } \\
\text { planar S2 } \\
\text { schistosity. }\end{array}$ \\
\hline $\begin{array}{l}\mathbf{D} \\
\mathbf{1}\end{array}$ & $\begin{array}{l}\text { Top- } \\
\text { to- } \\
\text { the } \\
\text { W- } \\
\text { NW } \\
\text { thrus } \\
\text { ting }\end{array}$ & $\begin{array}{c}\text { Main schistosity } \\
\text { (S1) }\end{array}$ & $\begin{array}{l}\text { Schistosity S1 with } \\
\text { km-size isoclinal } \\
\text { folds. }\end{array}$ & $\begin{array}{l}\text { Top- } \\
\text { to-the } \\
\text { W-NW } \\
\text { thrust } \\
\text { ing }\end{array}$ & $\begin{array}{l}\text { Schisoisity S1 } \\
\text { with km-size } \\
\text { isoclinal folds. }\end{array}$ \\
\hline
\end{tabular}

Table 1. 


\begin{tabular}{|c|c|c|c|c|c|c|c|c|c|}
\hline $\begin{array}{c}\text { sampl } \\
\text { e }\end{array}$ & rock & $\begin{array}{c}\text { longitud } \\
\mathbf{e}^{*}\end{array}$ & $\begin{array}{c}\text { latitud } \\
\mathbf{e}^{*}\end{array}$ & $\begin{array}{l}\text { altitud } \\
\text { e }\end{array}$ & $\mathbf{n}$ & Ral & std & $\underset{{ }^{\circ} \mathrm{C}}{\operatorname{Tmax}}$ & $\begin{array}{l}18, \\
{ }^{\circ} \mathrm{C}\end{array}$ \\
\hline $\begin{array}{l}\text { PLO8- } \\
56\end{array}$ & $\begin{array}{c}\text { Blackschi } \\
\text { st }\end{array}$ & 933065 & $\begin{array}{c}201542 \\
3\end{array}$ & 2662 & $\begin{array}{l}1 \\
1\end{array}$ & 0.6193 & 0.01 & 304 & 5.14 \\
\hline $\begin{array}{c}\text { PLO8- } \\
57\end{array}$ & $\begin{array}{c}\text { Blackschi } \\
\text { st }\end{array}$ & 933111 & $\begin{array}{c}201537 \\
5\end{array}$ & 2660 & $\begin{array}{l}1 \\
3\end{array}$ & 0.62 & 0.01 & 308 & 4.14 \\
\hline $\begin{array}{l}\text { PL08- } \\
58\end{array}$ & $\begin{array}{l}\text { Blackschi } \\
\text { st }\end{array}$ & 928110 & $\begin{array}{c}201130 \\
7\end{array}$ & 2570 & $\begin{array}{l}1 \\
4\end{array}$ & 0.61 & $\begin{array}{l}< \\
0.01\end{array}$ & 296 & 1.21 \\
\hline $\begin{array}{l}\text { PLO8- } \\
59\end{array}$ & $\begin{array}{l}\text { Blackschi } \\
\text { st }\end{array}$ & 928096 & $\begin{array}{c}201130 \\
9\end{array}$ & 2576 & $\begin{array}{l}1 \\
2\end{array}$ & 0.61 & 0.01 & 296 & 2.89 \\
\hline $\begin{array}{l}\text { PL08- } \\
\quad 68\end{array}$ & $\begin{array}{l}\text { Blackschi } \\
\text { st }\end{array}$ & 931201 & $\begin{array}{c}201286 \\
7\end{array}$ & 1904 & $\begin{array}{l}1 \\
6\end{array}$ & 0.59 & 0.01 & 274 & 4.18 \\
\hline $\begin{array}{l}\text { PL08- } \\
69\end{array}$ & $\begin{array}{l}\text { Blackschi } \\
\text { st }\end{array}$ & 930796 & $\begin{array}{c}201249 \\
9\end{array}$ & 2081 & $\begin{array}{l}1 \\
7\end{array}$ & 0.6 & 0.01 & 283 & 2.06 \\
\hline $\begin{array}{l}\text { PLO8- } \\
74\end{array}$ & $\begin{array}{c}\text { Sandston } \\
e\end{array}$ & 929840 & $\begin{array}{c}201591 \\
5\end{array}$ & 2114 & $\begin{array}{l}1 \\
0\end{array}$ & 0.6 & 0.01 & 283 & 4.09 \\
\hline $\begin{array}{l}\text { PLO8- } \\
76\end{array}$ & $\begin{array}{l}\text { Blackschi } \\
\text { st }\end{array}$ & 929333 & $\begin{array}{c}201731 \\
5\end{array}$ & 2379 & $\begin{array}{l}1 \\
5\end{array}$ & 0.61 & 0.01 & 292 & 2.32 \\
\hline
\end{tabular}

Table 2. 


\section{Chlorite}

\begin{tabular}{|c|c|c|c|c|c|}
\hline & $\mathrm{H} 1$ & $\mathrm{H} 2$ & $\mathrm{~A} 1$ & $\mathrm{~A} 2 \mathrm{~g} 1$ & $\mathrm{~A} 2 \mathrm{~g} 2$ \\
\hline $\mathrm{SiO}_{2}$ & 24.23 & 24.99 & 24.43 & 25.73 & 28.89 \\
\hline $\mathrm{TiO}_{2}$ & 0 & 0 & 0 & 0 & 0 \\
\hline $\mathrm{Al}_{2} \mathrm{O}_{3}$ & 22.44 & 22.18 & 21.36 & 21.52 & 20.93 \\
\hline $\mathrm{FeO}_{\text {total }}$ & 26.59 & 26.79 & 32.46 & 30.03 & 26.08 \\
\hline $\mathrm{MnO}$ & 0 & 0 & 0 & 0 & 0 \\
\hline $\mathrm{MgO}$ & 11.47 & 11.63 & 7.44 & 8.3 & 7.88 \\
\hline $\mathrm{CaO}$ & 0 & 0 & 0 & 0 & 0 \\
\hline $\mathrm{Na}_{2} \mathrm{O}$ & 0 & 0 & 0 & 0 & 0 \\
\hline $\mathrm{K}_{2} \mathrm{O}$ & 0 & 0 & 0 & 0 & 0 \\
\hline \multicolumn{6}{|c|}{ Atom site distribution ( 14 anhydrous oxygen basis including $\mathrm{Fe} 3+$ ) } \\
\hline $\mathrm{Si}_{(\mathrm{T} 1+\mathrm{T} 2)}$ & 2.66 & 2.7 & 2.71 & 2.78 & 3.09 \\
\hline $\mathrm{Al}_{(\mathrm{T} 2)}$ & 1.34 & 1.3 & 1.29 & 1.22 & 0.91 \\
\hline $\mathrm{Al}_{(\mathrm{M} 1)}$ & 0.24 & 0.23 & 0.14 & 0.14 & 0.13 \\
\hline $\mathrm{Mg}_{(\mathrm{M} 1)}$ & 0.3 & 0.28 & 0.3 & 0.23 & 0.18 \\
\hline $\mathrm{Fe}^{2+}{ }_{(\mathrm{M} 1)}$ & 0.34 & 0.3 & 0.29 & 0.22 & 0 \\
\hline $\mathrm{V}_{(\mathrm{M} 1)}$ & 0.12 & 0.19 & 0.27 & 0.41 & 0.69 \\
\hline$M g_{(\mathrm{M} 2+\mathrm{M} 3)}$ & 1.64 & 1.64 & 1.09 & 1.2 & 1.09 \\
\hline $\mathrm{Fe}^{2+}(\mathrm{M} 2+\mathrm{M} 3)$ & 2.12 & 1.97 & 2.38 & 1.97 & 1.52 \\
\hline $\mathrm{Al}_{(\mathrm{M} 2+\mathrm{M} 3)}$ & 0.24 & 0.39 & 0.53 & 0.83 & 1.39 \\
\hline $\mathrm{Al}_{(\mathrm{M} 4)}$ & 0.98 & 0.83 & 0.67 & 0.48 & 0.33 \\
\hline $\mathrm{Fe}^{3+}{ }_{(\mathrm{M} 4)}$ & 0.02 & 0.17 & 0.33 & 0.52 & 0.58 \\
\hline $\mathrm{Mg}_{(\mathrm{M} 4)}$ & 0 & 0 & 0 & 0 & 0.09 \\
\hline $\mathrm{XFe}{ }^{3+}$ & 1 & 7 & 11 & 19 & 25 \\
\hline Temperature & $371 *$ & $323 *$ & $275^{*}$ & $212 *$ & $106 * *$ \\
\hline
\end{tabular}




\section{Mica}

\begin{tabular}{|c|c|c|c|c|}
\hline & $\mathrm{H} 1$ & $\mathrm{H} 2$ & Alg1 & Alg2 \\
\hline $\mathrm{SiO}_{2}$ & 40.55 & 45.57 & 49.86 & 47.56 \\
\hline $\mathrm{TiO}_{2}$ & 0 & 0 & 0 & \\
\hline $\mathrm{Al}_{2} \mathrm{O}_{3}$ & 40.95 & 31.55 & 27.23 & 28.76 \\
\hline $\mathrm{FeO}_{\text {total }}$ & 1.61 & 1.94 & 2.89 & 3.59 \\
\hline $\mathrm{MnO}$ & 0 & 0 & 0.16 & 0.2 \\
\hline $\mathrm{MgO}$ & 1.55 & 0.83 & 2.39 & 1.45 \\
\hline $\mathrm{CaO}$ & 0.06 & 0.05 & 0.06 & 0.05 \\
\hline $\mathrm{Na}_{2} \mathrm{O}$ & 1.33 & 0.75 & 0.31 & 0.32 \\
\hline $\mathrm{K}_{2} \mathrm{O}$ & 6.19 & 8.56 & 9.6 & 9.48 \\
\hline \multicolumn{5}{|c|}{ Atom site distribution (11 anhydrous oxygen basis) } \\
\hline $\mathrm{Si}_{(\mathrm{T} 1+\mathrm{T} 2)}$ & 3.08 & 3.21 & 3.42 & 3.32 \\
\hline $\mathrm{Al}_{(\mathrm{T} 2)}$ & 0.92 & 0.79 & 0.58 & 0.68 \\
\hline $\mathrm{Al}_{(\mathrm{M} 1)}$ & 1.84 & 1.83 & 1.62 & 1.68 \\
\hline $\mathrm{Mg}_{(\mathrm{M} 1)}$ & 0.1 & 0.07 & 0.23 & 0.13 \\
\hline $\mathrm{Fe}_{(\mathrm{M} 1)}$ & 0.06 & 0.1 & 0.15 & 0.19 \\
\hline $\mathrm{V}_{(\mathrm{M} 2+\mathrm{M} 3)}$ & 0.89 & 0.97 & 0.98 & 0.97 \\
\hline$M g_{(\mathrm{M} 2+\mathrm{M} 3)}$ & 0.07 & 0.01 & 0.01 & 0.01 \\
\hline $\mathrm{Fe}_{(\mathrm{M} 2+\mathrm{M} 3)}$ & 0.04 & 0.02 & 0.01 & 0.02 \\
\hline $\mathrm{K}_{(\mathrm{A})}$ & 0.6 & 0.77 & 0.84 & 0.84 \\
\hline $\mathrm{Na}_{(\mathrm{A})}$ & 0.2 & 0.1 & 0.04 & 0.04 \\
\hline$V_{(A)}$ & 0.2 & 0.13 & 0.12 & 0.12 \\
\hline
\end{tabular}

Table 4. 


\section{References cited:}

Aillères, L., Bertrand, J.M., Macaudière, J., Champenois, M., 1995. Structure de la zone Houillère Briançonnaise (Alpes Françaises), tectonique néoalpine et conséquences sur l'interprétation des Zones Penniques Frontales. Comptes Rendus Acad. Sci. Paris 321, 247-254.

Agard, P., Goffé, B., Touret, J.L.R., Vidal, O., 2000. Retrograde mineral and fluid evolution in high-pressure metapelites (Schistes lustres Unit, western Alps). Contrib. Mineral. Petrol. 140, 296-315.

Agard, P., Jolivet, L., Goffé, B., 2001. Tectonometamorphic evolution of the Schiste Lustrés complex: implications for the exhumation of HP and UHP rocks in the Western Alps. Bulletin de la Société Géologique de France 172, 617-636.

Agard, P., Monié, L., Jolivet, L., Goffé, B., 2002. Exhumation of the Schistes Lustrés complex: in-situ laser probe 40Ar/39Ar constraints and implications for the Western Alps. J. Metam. Geol. 20, 599-618.

Barféty, J.C., Polino, R., Mercier, D., Caby, R., Fourneaux, J.C., 2006a. Carte géologique de la France au 1/50 000ème; Feuille de Névache-Bardonecchia-Modane. Orléans: BRGM, Feuille 799.

Barféty, J.C., Polino, R., Mercier, D., Caby, R., Fourneaux, J.C., 2006b Notice explicative de la feuille Névache-Bardonecchia-Modane à 1/50 000. Orléans: BRGM, 160p.

Battaglia, S., 2004. Variations in the chemical composition of illite from five geothermal fileds: a possible geothermometer. Clay Miner. 39, 501-510.

Bernet, M., 2009. A field-based estimate of the zircon fission-track closure temperature. Chem. Geol. 259, 181-189.

Bertrand, J.M., Aillères, L., Gasquet, D., Macaudière, J., 1996. The Pennine Front zone in Savoie (Western Alps) a review and new interpretations from the Zone Houillère Briançonnaise. Eclogae Geolociae Helvetiae 89, 297-320.

Berger, A., Bousquet, R., 2008. Subduction-related metamorphism in the Alps: review of isotopic ages based on petrology and their geodynamic consequences. Geol. Soc., London, Special Publication 298, 117-144.

Beyssac, O., Goffé, B., Chopin, C., Rouzaud, N., 2002. Raman spectra of carbonaceous material in metasediments : a new geothermometer. J. Metam. Geol. 20, 859-871.

Beyssac, O., Goffé, B., Petitet, J.P., Froigneux, E., Moreau, M., Rouzaud, J.N., 2003a. On the characterisation of disordered ans heterogeneous carbonaceous materials by Raman spectrometry. Spectrochimica Acta 59 , 2267-2276. 
Beyssac O., Brunet F., Petitet J.P., Goffe B., Rouzaud, J.N., 2003b. Experimental study of the microtextural and structural transformations of carbonaceous materials under pressure and temperature. European Journal of Mineralogy 15, 937-951.

Beyssac, O., Bollinger, L., Avouac, J.P., Goffe, B., 2004. Thermal metamorphism in the lesser Himalaya of Nepal determined from Raman spectroscopy of carbonaceous material. Earth and planetary Science Letters 225, 233-241.

Beyssac, O., Simoes, M., Avouac, J.P., Farley, K.A., Chen Y.G., Goffé, B., 2007. Late Cenozoic metamorphic evolution and exhumation of Taiwan. Tectonics 26, TC6001, pp. 32 .

Bishop, B.P., Bird, D.K., 1987. Variation in sericite compositions from fracture zones within the Coso Hot Springs geothermal system. Geocim. Cosmochim. Acta 51, 1245-1256.

Bousquet, R., Oberha, R., Goffé, B., Wiederkehr, M., Koller, F., Schmid, S.M., Schuster, R., Engi, M., Berger, A., Martinotti, G., 2008. Metamorphism of metasediments at the scale of an orogen: a key to the Tertiary geodynamic evolution of the Alps. Geol. Soc., London 298, 393-411.

Brandon, M.T., Roden-Tice, M.K., Garver, J.I., 1998. Late Cenozoic exhumation of the Cascadia accretionary wedge in the Olympic Mountains, northwest Washington State. Geol. Soc. Am. Bull. 110, 985-1009.

Cathelineau, M., 1988. Cation site occupancy in chlorites and illites as a function of temperature. Clay Minerals 23, 471-485.

Cathelineau, M., Nieva, D., 1985. A chlorite solid solution geothermometer The Los Azufres (Mexico) geothermal system. Contrib. Mineral. Petrol. 91, 235-244.

Caby, R., 1996. Low-angle extrusion of high-pressure rocks and the balance between outward and inward displacements of Middle Penninic units in the western Alps. Eclogae Geolociae Helvetiae 89, 229-267.

Ceriani, S., 2001. A combined study of structure and metamorphism in the frontal Penninic units between the Arc and Isère valley (Western Alps): Implications for the geodynamic evolution of the Western Alps. Phd, Basel. 196p. (unpublished).

Ceriani, S., Fugenschuh, B., Potel, S., Schmid, S.M., 2003. Tectono-metamorphic evolution of the Frontal Penninic units of the Western Alps: correlation between low-grade metamorphism and tectonic phases. Swiss Bull. Miner. Petrol. 83, 111-131.

Chopin, C., 1984. Coesite and pure pyrope in high-grade blueschists of the Western Alps. Contrib. Miner. Petro. 86, 107-118. 
De Andrade, V., Vidal, O., Lewin, E., O’Brien, P., Agard, P., 2006. Quantification of electron microprobe compositional maps of rock thin sections: an optimized method and examples. J. Metam. Geol. 24, 655-668.

Detraz, G., 1984. Etude géologique du bord interne de la zone Houillère Briançonnaise entre la vallée de l'Arc et le massif de Peclet-Polset (Alpes de Savoie). Thèse - Université scientifique et médicale de Grenoble. 163p. (unpublished).

Drits, V.A., McCarty, D.K., 2007. The nature of structure-bonded H2O in illite and leucophyllite from deshydratation and dehydroxylation experiments. Clay Clay Miner. $55,45-48$.

Dubacq, B., Vidal, O., De-Andrade, V., 2010. Dehydratation of dioctahedral aluminous phyllosilicates: thermodynamic modelling and implication for thermobarometric estimates. Contrib. Mineral. Petrol. 159, 159-174.

Fabre, R., 1982. Le paléozoïque briançonnais au Nord de Névache: Analyse des déformations alpines dans un secteur axial de la zone briançonnaise. Thèse Université scientifique et médicale de Grenoble. 397p. (unpublished).

Fabre, R., Gidon, M., Tricart, P., 1982. La structure du paléozoïque de la zone briançonnaise axiale au Nord de Névache. Géol. Alp. 58, 31-52.

Freeman, S.R., Inger, S., Butler, R.W.H., Cliff, R.A., 1997. Dating deformation using Rb-Sr in white mica: Greenschist facies deformation ages from the Entrelor shear zone, Italian Alps. Tectonics 16, 57-76.

Frey, M., Desmond, J., Neubauer, F., 1999. The new metamorphic map of the Alps; 1:500000; 1:1000000. Schweiz. Mineral. Petrogr. Mitt. 79, pp. 230.

Ford, M., Duchene, S., Gasquet, D., Vanderhaegue, O., 2006. Two-phase orogenic convergence in the external and internal SW Alps. J. Geol. Soc., London 163, 815826.

Fügenschuh, B., Schmid, S.M., 2003. Late stages of deformation and exhumation of an orogeny constrained by fission-track data: A case study in the Western Alps. GSA Bull. 115, 1425-1440.

Gabalda, S., 2008, Processus d'exhumation dans les Alpes occidentales : modélisation géométrique et reconstitution géodynamique sur la transversale ChartreuseMaurienne, une approche multi-échelle. Phd thesis, pp. 175. (unpublished).

Gabalda, S., Beyssac, O., Jolivet, L., Agard, P., Chopin, C., 2009. Thermal structure of a fossil subduction wedge in the Western Alps. Terra Nova 21, 28-34. 
Ganne, J., 2003. Les domes de socles HP-BT dans le domaine Pennique des Alpes nordoccidentales (massifs d'Ambin et de Vanoise Sud) : modalities de leur exhumation. Thèse, Université de Savoie, pp. 309. (unpublished).

Ganne, J., Bussy, F., Vidal, O., 2003. Multi-stage garnet in the internal Briançonnais basement (Ambin Massif, Savoy): new petrological constraints on the blueschistfacies metamorphism in the Western Alps and tectonic implications. J. Petro. 44, 1281-1308.

Ganne, J., Bertrand, J.M., Fudral, S., 2005. Fold interference pattern at the top of basement domes and apparent vertical extrusion of HP rocks (Ambin and South Vanoise massifs, Western Alps). J. Struct. Geol. 27, 553-570.

Ganne, J., Bertrand, J.M., Fudral, S., Marquer, D., Vidal, O., 2007. Structural and metamorphic evolution of the Ambin massif (western Alps): toward a new alternative exhumation model for the Brianconnais domain. Bull. Soc. Geol. France 178, 437458 .

Gerber, W., 2008. Evolution tectono-métamorphique du Briançonnais interne : Comportement du socle et de sa couverture dans un contexte de subduction continentale profonde. Phd, Université Pierre et Marie Curie (Paris), 306p. (unpublished).

Glodny, J., Lohrmann, J., Echtler, H., Gräfe, K., Seifert, W., Collao, S., Figueroa, O., 2005. Internal dynamics of a paleoaccretionary wedge: insights from combined isotope tectonochronology and sandbox modelling of the South-Central Chilean forearc. Earth and Planetary Sci. Lett. 231, 23-39.

Goffé, B., Schwartz, S., Lardeaux, J.M., Bousquet, R., 2004. Explanatory notes to the map: metamorphic structure of the Alps western and Ligurian Alps. Mitt. Osterr. Miner. Ges. 149, 125-144.

Graciansky, P.C., Roberts, D.G., Tricart, P., 2010. The Western Alps, from rift to passive margin to orogenic belt: an integrated geoscience overview. Elsevier, $429 \mathrm{p}$.

Guillot, S., Hattori, K., Agard, P., Schwartz, S., Vidal, O., 2009. Exhumation processes in oceanic and continental subduction contexts: a review. In S. Lallemand and F. Funiciello (eds.) "Subduction Zone Dynamics", Springer-Verlag Berlin Heidelberg., doi 10.1007/978-3-540-87974-9: 175-204,.

Handy, M.R., Schmid, S.M., Bousquet, R., Kissling, E., Bernoulli, D., 2010. Reconciling plate-tectonic reconstruction of Alpine Tethys with the geological-geophysical record of spreading and subduction in the Alps. Earth Sci. Rev. 102, 121-158.

Hillier, S. \& Velde, B., 1991. Octahedral occupancy and the chemical composition of diagenetic (Low-Temperature) Chlorites. Clay Miner. 26, 149-168. 
Inoue, A., Meunier, A., Patrier-Mas, P., Rigault, C., Beaufort, D., Vieillard, P., 2009. Application of Chemical Geothermometry to Low-Temperature Trioctahedral Chlorites. Clays Clay Miner. 57(3), 371-382.

Kilian, M.W., 1903. Sur le rôle des charriages dans les Alpes delphino-provençales et sur la structure en éventail des Alpes briançonnaises. Compte Rendu Acad. Sci. Paris 137, 536-537.

Lahfid, A., Beyssac, O., Deville, E., Negro F., Chopin, C., Goffé, B., 2010. Evolution of the Raman spectrum of carbonaceous material in low-grade metasediments of the Glarus Alps (Switzerland). Terra Nova 22, 354-360.

Lardeaux, J.M., Schwartz, S., Tricart, P., Paul, A., Guillot, S., Béthoux, N., Masson, F., 2006. A crustal-scale cross-section of the south-western Alps combining geophysical and geological imagery. Terra Nova 18, 412-422.

Le Fur, F., 1998. Etude structurale et cinématique d'un réseau alpin de veines de quartz (Plan Bouchet - Zone Houillère Briançonnaise). Géol. Alp. 75, 187-190.

Loucks, R.R., 1991. The bound interlayer $\mathrm{H}_{2} \mathrm{O}$ content of potassic white micas; muscovitehydromuscovite-hydrophyrophyllite solutions. Am. Mineral. 76, 1563-1579.

Malusà, M.G., Polino, R., Zattin, M., Bigazzi, G., Martin, S., Pianna, F., 2005. Miocene to present differential exhumation in the Western Alps: Insights from fission track thermochronology. Tectonics $24,1-23$.

Malusà, M.G., Vezzoli, G., 2006. Interplay between erosion and tectonics in the Western Alps. Terra Nova 18, 104-108.

Massonne, H.J., Schreyer, W., 1987. Phengite geobarometry based on the limiting assemblage with K-feldspar, phlogopite, and quartz. Contrib. Mineral. Petrol. 96, 212224.

Mercier, D., Beaudoin, B., 1987. Revision du carbonifère briançonnais : Stratigraphie et évolution du bassin. Géologie Alpine, Mém. h.s. 13, 25-31.

Munoz, M., De Andrade, V., Vidal, O., Lewin, E., Pascarelli, S., Susini, J., 2006. Redox and speciation micro-mapping using dispersive X-ray absorption spectroscopy: Application to iron in chlorite mineral of a metamorphic rock thin section. Geochem. Geophys. Geosyst. 7, Q11020.

Negro, F., Beyssac, O., Goffé, B., Saddiqi, O., Bouybaouene M., 2006 Thermal structure of the Alboran Domain in the Rif (northern Morocco) and the Western Betics (southern Spain). Constraints from Raman Spectroscopy of Carbonaceous Material. J. Metam. Geol. 24, 309-327. 
Parra, T., Vidal, O., Agard, P., 2002a. A thermodynamic model for Fe-Mg dioctahedral K white micas using data from phase-equilibrium experiments and natural pelitic assemblages. Contrib. Mineral. Petrol. 143, 706-732.

Parra, T., Vidal, O., Jolivet, L., 2002b. Relation between the intensity of deformation and retrogression in blueschist metapelites of Tinos Island (Greece) evidenced by chloritemica local equilibria. Lithos 63, 41-66.

Putnis A., Austrheim, H., 2010. Fluid-induced processes: metasomatism and metamorphism. Geolfuid 10, 254-269.

Rolland, Y., Lardeaux, J.M., Guillot, S., Nicollet, C., 2000. Syn-convergence extension, vertical pinching and contrasted metamorphic units on the Western edge of the Gran Paradiso massif (French-Italian Alps). Geodinamica Acta 13, 133-148.

Saliot, P., 1978. Le métamorphisme dans les Alpes françaises. Thèse, Université d'Orsay, Orsay. 183p. (unpublished).

Sanchez, G., Rolland, Y., Corsini, M., Oliot, E., Goncalves, P., Schneider, J., Verati, C., Lardeaux, J.M., Marquer, D., 2011. Dating Low-Temperature deformation by 40Ar/39Ar on white mica, insights from the Argentera-Mercantour Massif (SW Alps). Lithos 125, 521-536.

Schwartz, S., 2000. La zone piémontaise des Alpes occidentales : un paléo-complexe de subduction. Arguments métamorphiques, géochronologiques et structuraux. Thèse/Phd, Université Claude Bernard - Lyon; 392 p. (unpublished).

Schwartz, S., Lardeaux, J.M., Tricart, P., Guillot, S., Labrin, E., 2007. Diachronous exhumation of HP-LT metamorphic rocks from south-western Alps: evidence from fission-track analysis. Terra Nova 19, 133-140.

Schwartz, S., Tricart, P., Lardeaux, J.M., Guillot, S., Vidal, O., 2009 Late tectonic and metamorphic evolution of the Piedmont accretionary wedge (Queyras Schistes lustés, western Alps): Evidences for tilting during Alpine collision. GSA Bul. 121, 502-518.

Simon-Labric, T., Rolland, Y., Dumont, T., Heymes, T., Authemayou, C., Corsini, M., Fornari, M., 2009. ${ }^{40} \mathrm{Ar} /{ }^{39} \mathrm{Ar}$ dating of Penninic Front tectonic displacement (Western Alps) during the Lower Oligocene (31-34 Ma). Terra Nova 21, 127-136.

Smith, D.C., 1984. Coesite in clinopyroxene in the Caledonides and its implication for geodynamics. Nature 310, 641-644.

Schmid, S.M., Kissling, E., 2000. The arc of western Alps in the light of geophysical data on deep crustal structures. Tectonics 19, 62-85.

Spear, F.S. 1993. Metamorphic phase equilibria and Pressure-Temperature-time paths. Mineral. Soc. Am., Washington, DC. pp 799. 
Sterzerzynski, P., Guillot, S., Leloup, P.H., Arnaud, N., Vidal, O., Ledru, P., Courrioux, G., Darmendrail, X., this issue. Structural-metamorphic and ${ }^{40} \mathrm{Ar}-{ }^{39} \mathrm{Ar}$ analysis in the Briançonnais zone (Modane Aussois area, Lyon Turin transect, Western Alps). Integration in the Alpine framework. J. Geodynamics

Tagami, T., Ito, H., Nishimura, S., 1998. Thermal annealing characteristics of spontaneous fission tracks in zircon. Chem. Geol. 80, 159-169.

Tricart, P. 1980. Tectoniques superposées dans les Alpes occidentales au Sud du Pelvoux. Evolution structurale d'une chaîne de collision. Thèse, Institut de Géologie, Strasbourg. 407p. (unpublished).

Tricart, P., 1984 From passive margin to continental collision - a tectonic scenario for the Western Alps. Am. J. Sci. 284, 97-120.

Tricart, P., Schwartz, S., 2006. A north-south section across the Queyras Schistes Lustrés (Piedmont zone, Western Alps): Syn-collision refolding of a subduction wedge. Eclogae Geologicae Helvetiae 99, 429-442.

Tricart, P., Van der Beek, P., Schwartz, S., Labrin, E., 2007. Diachronous late-stage exhumation across the western Alpine arc: constraints from apatite fission-track thermochronology between the Pelvoux and Dora-Maira Massifs. J. Geol. Soc. , London 164, 163-174.

Velde, B., 1965. Phengite micas; synthesis, stability, and natural occurrence. Am. J. Sci. 263, 886-913.

Vidal, O., Parra, T., 2000. Exhumation paths of high-pressure metapelites obtained from local equilibria for chlorite-phengite assemblages. Geol. J. 35, 139-161.

Vidal, O., Parra, T., Trotet, F., 2001. A thermodynamic model for Fe-Mg aluminous chlorite using data from phase equilibrium experiments and natural pelitic assemblages in the $100-600^{\circ} \mathrm{C} 1-25 \mathrm{Kbar}$ range. Am. J. Sci. 63, 557-592.

Vidal, O., Parra, T., Vieillard, P., 2005. Thermodynamic properties of the Tschermak solid solution in Fe-chlorite: Application to natural examples and possible role of oxidation. Am. Min. 90, 347-358.

Vidal, O., De Andrade, V., Lewin E., Munoz M., Parra, T., Pascarelli, S., 2006. P-Tdeformation-Fe3+/Fe2+ mapping at the thin section scale and comparision with XANES mapping. Application to a garnet-bearing metapelite from the Sambagawa metamorphic belt (Japan). J. Metam. Geol. 24, 669-683.

Vidal, O., Dubacq, B., 2009. Thermodynamic modelling of clay dehydration, stability and compositional evolution with temperature, pressure and water activity. Geochem. Cosmo. Acta 73, 6544-6564. 
Vidal, O., Dubacq, B., Lanari, P., 2010. Comment on "the role of $\mathrm{H} 3 \mathrm{O}+$ in the crystal structure of illite" by F. Nieto, M. Melini and I. Abad. Clays and Clay Minerals 58(5), 717-720.

Young, D.Y., Hacker, B.R., Andersen, T.B., Corfu, F., 2007. Prograde amphibolite facies to ultrahigh-pressure transition from Nordfjord, western Norway: implications for exhumation tectonics. Tectonics 26: doi:10.1029/2004TC001781.

Zang, W., Fyfe, W.S., 1995. Chloritization of the hydrothermally altered bedrock at the Igarapé Bahia gold deposit, Carajas, Brazil. Mineral. Deposita 30, 30-38. 